九州大学学術情報リポジトリ

Kyushu University Institutional Repository

Early Permian Brachiopods from the Kawai Limestone, Hiroshima Prefecture, Southwest Japan

Yanagida, Juichi

Faculty of Science, Kyushu University

https://doi.org/10.5109/1546095

出版情報：九州大學理學部紀要：Series D，Geology. 25 (2)，pp.159-197，1984-11-15. Faculty of Science, Kyushu University バージョン：

権利関係 : 
Mem. Fac. Sci., Kyushu Univ., Ser. D, Geol., Vol. XXV, No. 2, pp. 159-197, text-figs. 1-18, table 1, plates 16-21, November 15, 1984

\title{
Early Permian Brachiopods from the Kawai Limestone, Hiroshima Prefecture, Southwest Japan*
}

\author{
Juichi YANAGIDA and Isao NISHIKAWA
}

\begin{abstract}
A Lower Permian brachiopod fauna from the Kawai Limestone distributed in the Joge area, northeastern Hiroshima Prefecture, Southwest Japan, was investigated. It is composed of 18 species among 15 genera, mostly collected from two localities at a close distance. A new trigonirhynchiid genus, Nipponirhynchia, is proposed. The limestone containing this fauna is correlated with the Lower Permian Yaikian of the USSR standard in the Tethysian province.
\end{abstract}

\section{Introduction}

A thick series of Carboniferous and Permian limestones called the Kawai Limestone (SADA, OKIMURA, and IMAMURA, 1979) is widely but sporadically distributed mainly along shallow valleys in the Kawai-Kogoro area, northeastern part of Hiroshima Prefecture. Details of geology of this area are introduced by SADA, OKIMURA, and IMAMURA (1979) with a geological map and a locality map of fusulines and brachiopods.

The junior author was engaged in collecting fossils for long years from various localities of this region. Most of the brachiopod collection described in this paper were obtained by the junior author himself from three localities in the Kogoro area together with some associated fossils, such as a trilobite pygidium, corals, and gastropods. These localities respectively correspond to $\mathrm{K}-1, \mathrm{~K}-2$, and K-3 (or KW-46) of SADA et al. as shown in the Text-fig. 1. Limestones including these fossils are strongly recrystallized by volcanic activity of the Cretaceous Takada rhyolitic rocks which widely distribute in the Kawai Limestone area. Therefore the detail of lithofacies of limestone and occurrence of brachiopods is very difficult to understand.

We express our sincere thanks to Professor Kimiyoshi SADA of Hiroshima University for his kind guidance to the field and giving us hearty facility in the trip. We are also indebted to Mr. Michiaki YoKoyama of the Attached High School of Hiroshima University for his kind cooperation during our field trip. We sincerely appreciate the Shinami Primary School of Joge for her kindness of giving us facilities of examining some specimens of the school collection. Finally, we would like to express our sincere gratitude to Dr. Teiichi KoBAYASHI and the late Dr. Ichiro HAYASAKA for their continuous warm encouragement. This work was financed by the Scientific Research Fund of the Ministry

* Studies of Japanese Trilobites and Associated Fossils XXXV. Manuscript received July 20, 1984. 


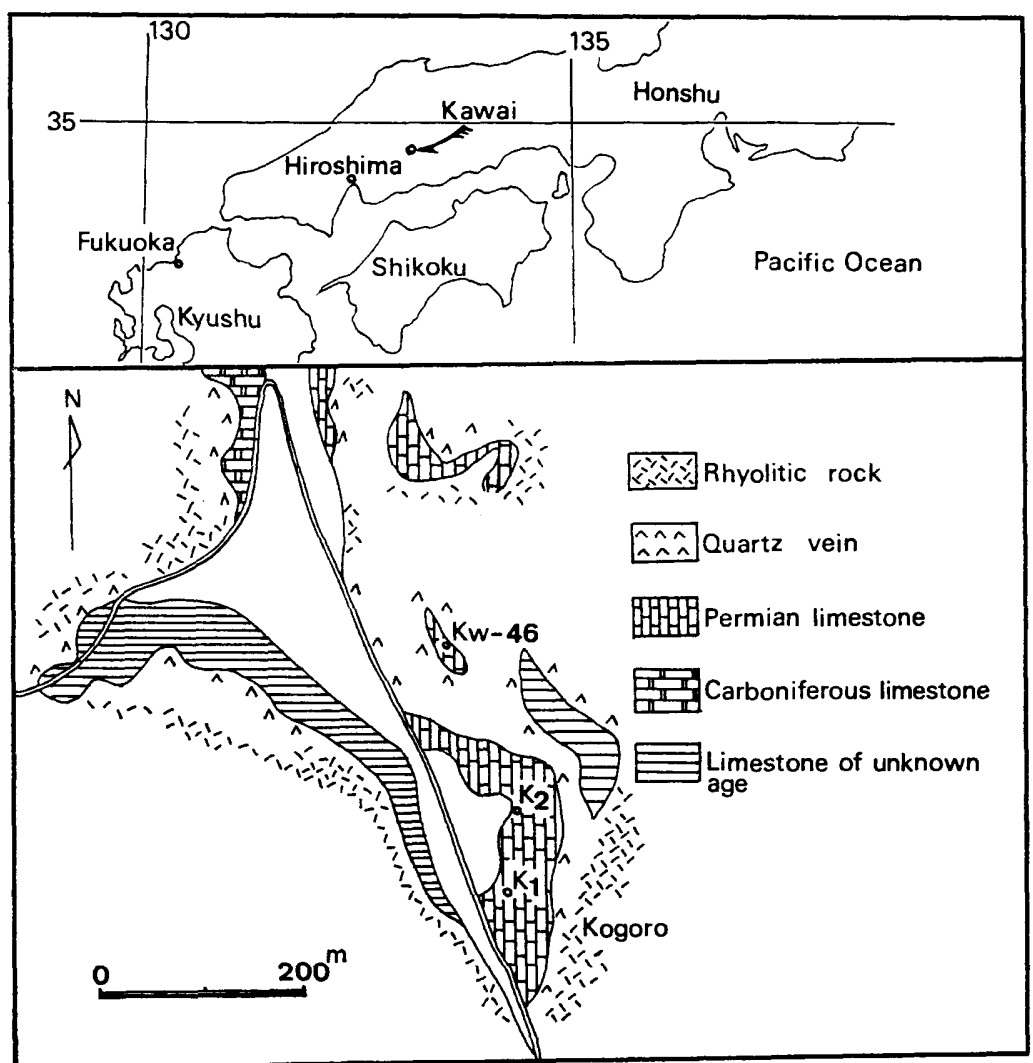

Fig. 1. An index and a brief geological map showing localities of the Lower Permian brachiopods (Geological map is partly shown after SADA, OKIMURA, and IMAMURA, 1979).

of Education and the field work was also financed by the Grant-in Aid for Scientific Research from the Japan Academy.

It is our great pleasure to acknowledge with thanks for joining this occasion in honoring Professor Tsugio SHuTo by dedicating this paper.

\section{Remarks on the Kawai Limestone brachiopod fauna}

We discriminated 18 species and 15 genera of brachiopods from three localities, K-1, K-2, and K-3=KW-46 from south to north. They are located respectively at a distance of about $100 \mathrm{~m}$ and $200 \mathrm{~m}$, very close to a route from Kogoro to Kawai. The faunal elements are shown in Table 1.

Among the rhynchonellacean species Nipponirhynchia shutoi, new genus and new species, is very important for faunal comparison. Many species with completely costate uncinuliform have been reported under a generic name Uncinulus from several regions in Asia. Among them a specimen described by BroILI (1916, pl. 12, fig. 12) as Uncinulus timorensis BEYRICH from the Lower Permian of Bituani, Timor, is externally very close to the present species. It 
Table 1. Distribution of brachiopods in the Kawai Limestone with number of individuals.

\begin{tabular}{|c|c|c|c|}
\hline \multirow{2}{*}{ Species } & \multicolumn{3}{|c|}{ Locality } \\
\hline & $\mathrm{K}-1$ & $\mathrm{~K}-2$ & $\begin{array}{c}\mathrm{KW}-46 \\
(\mathrm{~K}-3)\end{array}$ \\
\hline Nipponirhynchia shutoi, n. gen. and n. sp. & & 5 & \\
\hline Uncinunellina hayasakai, n. sp. & & 7 & \\
\hline Stenoscisma japonica, n. sp. & & 5 & \\
\hline Pugnacidae gen. and sp. indet. & & 2 & \\
\hline Paraspiriferina sp. & & 4 & \\
\hline Callispirina sp. & & 3 & \\
\hline Composita jogensis, n. sp. & & 15 & \\
\hline Crurithyris sp. & & 1 & \\
\hline Martinia nipponica, n. sp. & 2 & & \\
\hline Elivella aff. bashkirica (TSCHERNYSCHEW) & & 1 & \\
\hline Hustedia aff. $H$. ratburiensis WATERHOUSE and PIYASIN & & 1 & \\
\hline Purdonella sadai, n. sp. & 1 & 4 & \\
\hline Purdonella sp. & 1 & 1 & \\
\hline Neophricadothyris kawaiensis, n. sp. & & 8 & \\
\hline Neophricadothyris aff. N. catatona CoOPER and GRANT & & 4 & \\
\hline Neophricadothyris? sp. & & 1 & \\
\hline Kutorginella? sp. & & 2 & \\
\hline Dielasma sp. & 3 & 7 & 1 \\
\hline Chondronia hiroshimensis, n. sp. & & 11 & \\
\hline
\end{tabular}

is highly probable that the Bituani specimen belongs to Nipponirhynchia, if the internal character is examined on the Timor specimens.

Uncinunellina hayasakai, n. sp., together with Stenoscisma japonica, n. sp., is characteristically very small and in having a uniformly small size $U$. hayasakai is distinct from other known species of Uncinunellina. Stenoscisma japonica may be related with $S$. tanankouensis (OzAKI) from the Lower Permian of the Taiyuan Series of Northeast China.

Paraspiriferina sp. and Callispirina sp. are also characterized by their very small size even in the adult stage. Paraspiriferina gentilis GRANT from the Lower Permian of Ko Muk island, Southern Thailand, may be related to Paraspiriferina sp.

Composita jogensis, n. sp., has close relation to $C$. advena GRANT from the Lower Permian of the same island in Southern Thailand. Composita jogensis is relatively common in occurrence in the present fauna.

It is interesting and noteworthy as GRANT (1976) indicated that the occurrence of Composita which is the Permian most common genus in the Americas and very rare in Asia well shows the faunal communication at that time between these far distant regions. The present fauna also does not contain the typical Asian genus Spirigerella which is very similar to Composita. Other evidences for supporting the faunal links between Japan and the Americas in Early Permian time are also provided by a newly found, typically American genus, 
Chondronia and occurrence of Neophricadothyris aff. N. catatona. Chondronia is very small, and rather few in occurrence even in the Wolfcampian and Leonardian of North America. Six American species of this genus are all found from biohermal limestones of West Texas. Neophricadothyris aff. N. catatona is closely related to the named species from the Lower Permian Wolfcampian in West Texas (COOPER and GRANT, 1976).

Hustedia aff. $H$. ratburiensis is closely related to the named species from the Lower Permian of Southern Thailand.

Purdonella sadai, n. sp., and P. sp. have their alliances in the Upper Carboniferous to Middle Permian of Thailand, China, the Salt Range, and the Urals.

Neophricadothyris kawaiensis, n. sp., is externally very similar to some forms described and figured by GRABAU (1934) under the name of Phricodothyris rostrata (KUTORGA) from the Lower Permian Maping Limestone of South China. This Chinese species would possibly be congeneric with Neophricadothyris, if the nature of the spiral cones is investigated.

Dielasma sp. also shows a close alliance to Dielasma itaitubense TSCHERNYSCHEW in the Maping Limestone (GRABAU, 1934). The Chinese specimens of this species, however, all have undoubtedly rectimarginate anterior commissure, and in this point they are clearly distinct from those of the TSCHERNYSCHEW's species.

Summarizing faunal characteristics, it appears that the Kawai brachiopod fauna is closely related not only to the Lower Permian faunas in some regions in Asia, such as the Taiyuan Series in North China and the Maping Limestone in South China, the lower part of the Rat Buri Limestone in Southern Thailand, and the Lower Permian of the Bituani area, Timor, but also to the Wolfcampian and Leonardian faunas of the Lower Permian of West Texas, North America. It also has links in faunal elements to the Lower Permian faunas of the Salt Range and those far west of the Urals.

Among the Lower Permian brachiopod faunas in Japan the Nakakubo fauna from the Nakakubo Formation of Shikoku in the outer zone of Southwest Japan has some generic links to the present fauna, such as Uncinunellina and Callispirina but the faunal communication is not strong.

As stated above the Kawai brachiopod fauna is easily referable to the Early Permian in age, that is the Yaikian in the Tethysian standard. If we want to try the more detailed correlation of the present fauna, there is a way to discuss it in relation with fusuline data. SADA et al. (1979) found many fusulines from the Kawai Limestone ranging from Carboniferous to Permian. They discriminated Triticites ? sp. from a limestone at KW-2, about $50 \mathrm{~m}$ south of $\mathrm{K}-1$ where Dielasma sp., Purdonella sp., P. sadai, n. sp., and Martinia nipponica, n. sp., occur. On the other hand Pseudofusulina sp. was found from a limestone at K-3 (=KW-46) where we discriminated Dielasma sp., the same species from K-1 and K-2 limestones. Taking these fusulines data into consideration it is highly probable that the age of the brachiopod assemblage from K-1 is referable to Asselian and those from K-2 and K-3 are assigned to the Sakmarian, respectively the Early and Medial Yaikian of the USSR standard by Leven (1981). 


\section{Systematic Palaeontology}

Order Rhynchonellida KUHN, 1949

Superfamily Rhynchonellacea GRAY, 1848

Family Trigonirhynchiidae McLareN, 1965

Genus Nipponirhynchia, new genus

Type-species.-Nipponirhynchia shutoi, new genus and new species.

Diagnosis.-Shells of small size and uncinuliform in shape; fold and sulcus broadly developed in anterior half of shell; anterior and lateral margins truncated with uniplicate commissure; shell surface completely costate with simple tight costae, originating at beak.

Pedicle valve interior with thin dental plates, partly welded in wall; teeth small. Brachial valve interior with divided hinge plate; sockets deep with sharp socket ridges; crural bases strongly projected ventrocentrally and supported by a pair of thick crural plates, making a longitudinally deep rounded septalium; median septum duplex and very stout, continuous to crural plates.

Discussion.-Present genus is characterized by its uncinuliform shape with completely costate shell surface and a very strong duplex median septum, supporting a septalium in brachial valve. The one described genus having strong similarity to Nipponirhynchia is Uncinunellina. As the matter of fact if the internal structures are not taken into the consideration, generic distinction between completely costate form and semicostate form is very difficult. GRABAU, for example, who established Uncinunellina put both forms into the genus ( $U$. mongolicus GraBAU, 1931, pl. 5, figs. 7, 8; U. wangenheimi (PANDER), GrabaU, 1936, pl. 18, figs. 1, 2). There are also costate forms in U. timorensis BEYRICH and $U$. jabiensis WAagen by Broll (1916) from the Permian of Timor.

GRANT (1976) first examined the internal structures of $U$. theobaldi, the type-species of the genus by the silicified topotype material from the Salt Range and recognized short dental plates in pedicle valve and divided hinge plate without cardinal process or median septum in brachial valve. Internal structures of the preceding Asian costate forms of "Uncinunellina" are unknown at all. These costate forms are variable in outline, someones are transverse and others are rounded. It is necessary to confirm the internal structure of the costate forms of "Uncinunellina" to ascertain the generic position of this very common form in the Asian Permian.

Nipponirhynchia shutoi, new species

Pl. 16, Figs. 1-4

1916. Rhynchonella (Uncinulus) timorensis, Brolli, p. 59, pl. 126 (12), fig. 12.

Material.-Holotype, GK-D 31600 (pl. 16, fig. 1) ; Paratypes, GK-D 31646 (pl. 16, fig. 2), GK-D 31642 (pl. 16, fig. 4), GK-D 31655 (pl. 16, fig. 3). Two incomplete specimens also available.

Diagnosis.-As for genus.

Description.-Shell small to medium, transversely subpentagonal in outline with width about 1.3 times as wide as length; greatest width slightly anterior 


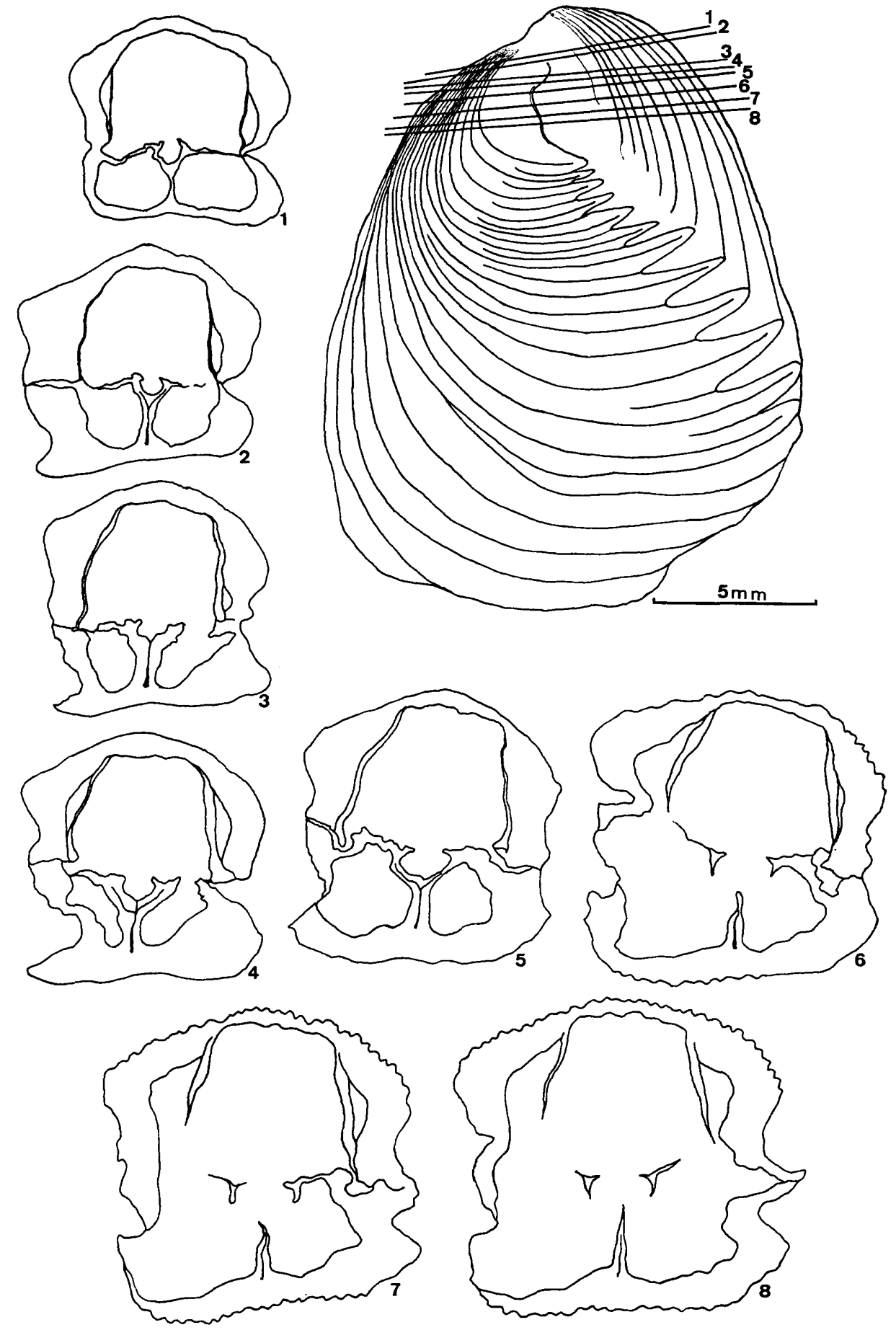

Fig. 2. Nipponirhynchia shutoi, n. gen. and n. sp. Serial transverse sections of posterior region of the holotype, GK-D 31600 . 
to midlength; posterior margin slightly concave, lateral margins slightly convex and anterior margin gently truncated. Both valves strongly and completely costate, costae simple, subangular, tightly arranged, counting about 40 on each valve with narrow and deep intercostal furrows. Fold and sulcus ornamented by 13 to 14 costae, respectively. Marginal spines project from extremities of intercostal furrows of both valves along anterior margin, fitting with interiors of corresponding costae of opposite valve.

Pedicle valve unequal in convexity, posterior half gently convex with largest convexity at a slight distance from beak, anterior half broadly concave in anterior profile and gently convex in lateral profile. Beak slightly broken, suggested to be narrow and pointed; beak ridges slightly developed, ventral profile of each shoulder weakly spreading; sulcus originates at about a-third of length from beak as a broad depression and occupies about five-eighths of width at anterior martin; tongue long and strongly convex but not geniculated, making a wide flat area together with anterior margin of fold of opposite valve.

Brachial valve moderately convex posteriorly and also at anterior margin, median part very slightly convex; flanks steep, slightly concave; fold broad, corresponding to sulcus of opposite valve, anterior margin of fold ventrally geniculate and unites with pedicle valve in a form of elliptical plane.

Pedicle valve interior with thin and short dental plates, supporting small teeth and often becoming obsolete in cosequence of welding to lateral walls.

Brachial valve interior with short divided hinge plates, deep sockets, deep septalium and thick crural plates, and thick duplex median septum. Outer hinge plates thick posteriorly with median elevation, median part decreasing height anteriorly and centrally depressed near anterior margin, anteriorly continuous to crura of falcifer type (COOPER and GRANT, 1976) through strong, ventromedially projected crural bases; sockets deep with sharp inner socket ridges; crural plates poseteriorly very thick, continuous to thick duplex median septum, making a trough like septalium; median septum short, about a-seventh of length of valve, rapidly decreasing height and strength at anterior to septalium.

Measurements in $\mathrm{mm}$.

\begin{tabular}{lcccc} 
& length & width & thickness & $\begin{array}{c}\text { width of sulcus } \\
\text { \& fold }\end{array}$ \\
\hline Holotype (GK-D 31600) & 18.5 & 24.0 & 21.7 & 13.5 \\
Paratype (GK-D 31655) & 11.0 & 13.2 & 11.0 & 9.5 \\
Paratype (GK-D 31646) & 19.5 & 21.2 & 14.5 & ca10
\end{tabular}

Remarks.-Nipponirhynchia shutoi is externally characterized by its transversely subpentagonal outline, truncated anterior region with a uniplicate anterior commissure in a elliptical plane, and completely costate surface. Internal characters of $N$. shutoi are represented by its divided hinge plates, very thick duplex median septum with developed septalium. The external configuration of the present species strongly resembles uncinuloid group. Uncinuliform shells commonly occur in the Permian of Asia. Of them some are characterized by their clearly costate valves including the beak region. The nearest form to Nipponirhynchia shutoi was described by BroILI (1916) from the Lower Per- 
mian of Bituani, Timor under the name of Rhynchonella (Uncinulus) timorensis BEYRICH (pl. 12, fig. 12). The external difference between the Bituani and Japanese species is that the former shows the occasional bifurcation of costae. The bifurcation is not observable at all in the Japanese species. Such being the case internal structures of the Bituani form are expected to be examined. Other costate forms from Permian of Timor (Broll, 1916, pl. 13, figs. 2 and 3, described as $U$. timorensis; pl. 13, figs. 4-6, described as $U$. jabiensis) are all characterized by the less transverse form, narrower beak, fewer costae, comparing with the Japanese species. Anterior commissure of them also does not exist on a plane like the other. Stratigraphically they occur from the Basleoian and much younger than the Bituani form and also N. shutoi.

GRANT (1976) described an indeterminable species of costate form under the name of Uncinunellina? from the Lower Permian of Ko Muk, Southern Thailand. This form, however, is easily distinguishable from $N$. shutoi by its dissimilar shape of anterior portion of shell from the typical uncinuliform.

Among figured specimens of Uncinulus mongolicus by GraBAU (1931) two small ones (pl. 6, figs. 3, 4) are similar to the Japanese specimens in their completely costate valves and pentagonal outline. The former, however, is less transverse and has much fewer costae than the latter.

Occurrence.-K-2

\section{Family Wellerellidae LIKHAREV in RzHONSNITSKAYA, 1956 \\ Genus Uncinunellina GraBAU, 1932 \\ Type-species.-Uncinulus theobaldi WAAGEN, 1884 \\ Uncinunellina hayasakai, new species}

Pl. 16, Figs. 5-7

Material.-Holotype, GK-D 31644 (pl. 16, fig. 7) ; Paratypes, GK-D 31653 (pl. 16, fig. 5), 31648 (pl. 16, fig. 6), and GK-D 31658. Beside types five complete shells also available under heading. Internal structures of cardinalia shown by serial sections of a paratype, GK-D 31658.

Diagnosis.-Shell small, pentagonal with straight and nearly truncated lateral margins; sulcus and fold broad with about 10 simple costae on each of them; anterior margin strongly truncated with high tongue, width of truncated part occupies about three-fifths of shell width.

Description.-Shell slightly wider than long; both valves unequally convex with strongly geniculated anterior portion. Pedicle valve weakly convex posteriorly with sharply pointed beak and clear beak ridges; apical angles very large of about $120^{\circ}$; median part of pedicle valve flattened and anteriorly broadly concave in anterior profile; broad sulcus originates at about a-third of length from beak, anteriorly with a strong geniculation and a long tongue, making a wide truncated plane at anterior margin and occupying about three-fifths of shell width; lateral wings very slightly convex with sharply truncated lateral margins; surface posteriorly smooth; costae begin at about slightly posterior to midlength, simple, subrounded with sharp and narrow intercostal furrows, and countable about 33 along margin. Brachial valve moderately convex with broad fold, originating at about midlength; anterior margin of fold sharply 


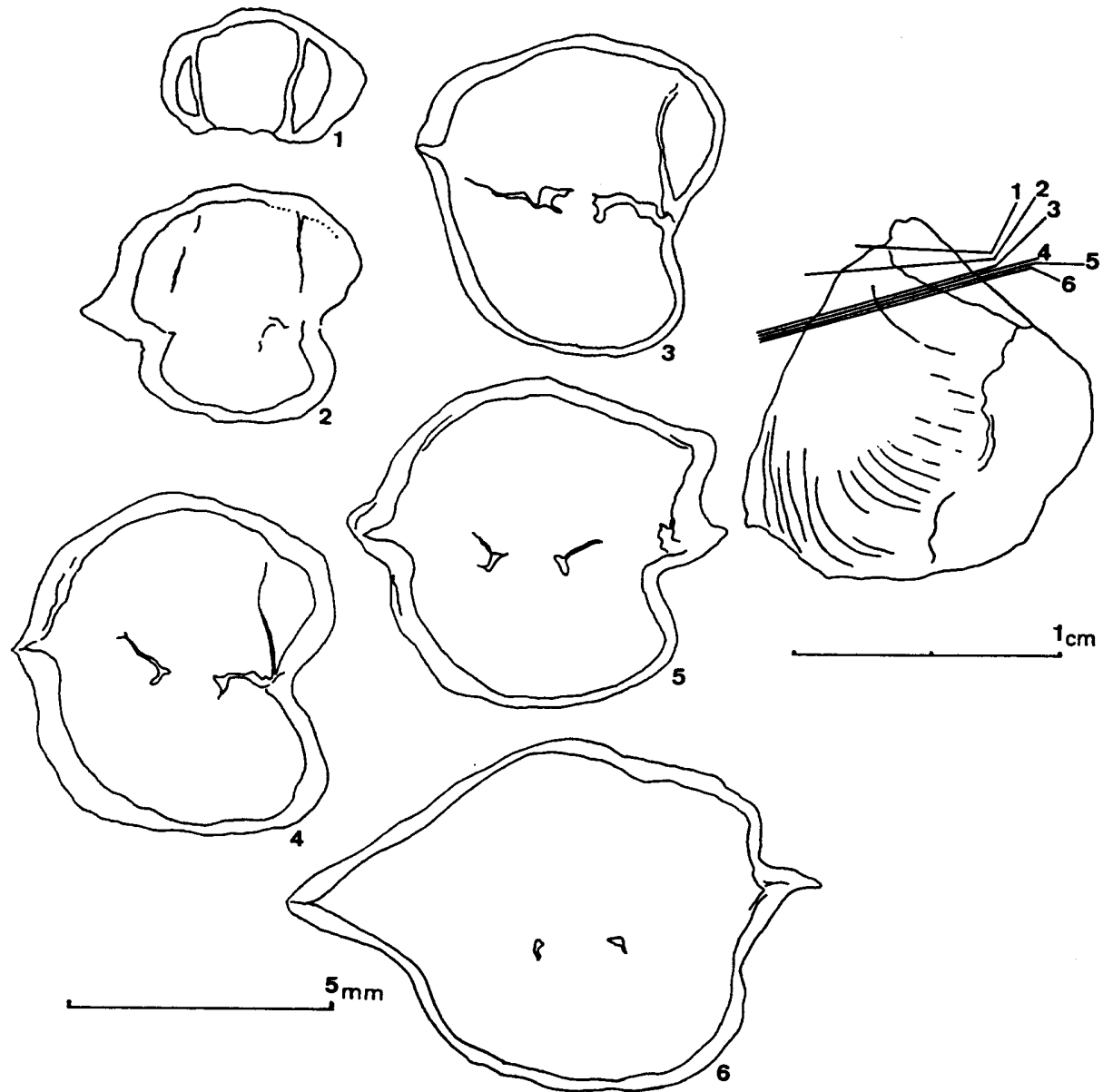

Fig. 3. Uncinunellina hayasakai, n. sp. Serial transverse sections of posterior region of a paratype, GK-D 31658.

geniculated; lateral slopes very steep; ornamentation same with opposite valve. Anterior commissure strongly uniplicate; marginal spines project from margins of intercostal furrows of both valves to inside of crests of costae of opposite valve.

Pedicle valve interior with thin short dental plates. Brachial valve interior with divided hinge plates and crura of falcifer type and neither cardinal process nor median septum.

Measurements in $\mathrm{mm}$ and degree.

\begin{tabular}{|c|c|c|c|c|c|c|c|}
\hline & length & width & $\begin{array}{l}\text { thick- } \\
\text { ness }\end{array}$ & $\begin{array}{l}\text { width of } \\
\text { sulcus \& } \\
\text { fold at } \\
\text { anterior } \\
\text { margin }\end{array}$ & $\begin{array}{c}\text { number } \\
\text { of costae } \\
\text { on fold } \\
\& \\
\text { sulcus }\end{array}$ & $\begin{array}{c}\text { number } \\
\text { of costae } \\
\text { on } \\
\text { lateral } \\
\text { slopes }\end{array}$ & $\begin{array}{l}\text { apical } \\
\text { angle }\end{array}$ \\
\hline Holotype (GK-D 31644) & 10.5 & 12.8 & 7.5 & 9.4 & 11 & 28 & $124^{\circ}$ \\
\hline Paratype (GK-D 31653) & 12.0 & 14.3 & 9.5 & 10.1 & 12 & 22 & $112^{\circ}$ \\
\hline Paratype (GK-D 31658) & 11.3 & 13.5 & 10.8 & 9.3 & 11 & 18 & \\
\hline (GK-D 31656) & 12.6 & 16.1 & 9.9 & 11.9 & 10 & 24 & $116^{\circ}$ \\
\hline (GK-D 31657) & 12.0 & 15.8 & 10.8 & 9.0 & 9 & 28 & $118^{\circ}$ \\
\hline
\end{tabular}


Remarks.-Uncinunellina hayasakai is characterized by its small pentagonal outline with sharply truncated and highly elevated anterior margin and also by steep lateral margins. In these points of views it is clearly distinguished from known species of Uncinunellina. Among species of Uncinunellina, $U$. theobaldi (WAAGEN) from the Permian of the Wargal Limestone of the Salt Range and U. mitigata GraNT from the Lower Permian of Kho Muk, Southern Thailand are close to the present species. U. theobaldi, however, is more transverse and less pentagonal than U. hayasakai. The lateral profile of the latter species is much more wedge-shaped than the former. U. mitigata also has the more rounded pentagonal outline and the lateral profile is more roundly wedge-shaped than $U$. hayasakai.

Occurrence.-K-2

Family Pugnacidae Rzhonsnitskaya, 1956

Pugnacidae genus and species undetermined

Pl. 17, Fig. 4

Material.-Only two specimens available and internal characters partly recognizable by two serial sections of the figured specimen, GK-D 31603.

Descriptive remarks.- Shell small, nearly equidimensional, posterior half angular and anterior half subrounded in outline with widest part at slightly anterior to midlength. Pedicle valve slightly convex with largest convexity at slightly anterior to beak; sulcus broad with weakly elongated tongue at anterior margin, originating at midlength as a broad flat bottom; beak pointed and tiny pedicle opening suggested to be existed; shoulders slightly concave in ventral view with apical angle of about $90^{\circ}$. Brachial valve longitudinally weakly convex with largest convexity near posterior margin and transversely strongly convex with a broad, round-topped fold along crest, originating at slightly posterior to midlength; anterior commissure strongly uniplicate. Both valves mostly smooth, only ornamented by very fine growth lines. Internal structures fragmentarily preserved. Pedicle valve interior with weak dental plates; brachial valve interior with divided hinge plates and strong crural base; median septum obsolete.

Measurements in $\mathrm{mm}$ and degree of 2 specimens.

\begin{tabular}{ccccc} 
& length & width & thickness & apical angle \\
\hline (GK-D 31603) & 16.0 & 16.4 & 13.5 & 94 \\
(GK-D 31604) & ca 11 & 12.0 & 4.3 & 92
\end{tabular}

Generic discrimination of present specimens are very difficult by these characters above stated. Dental plates, divided hinge plates, and the shell outline well indicate that they belong to Pugnacidae. Externally they are closely similar to those of Sichuanrhynchus sulcatus described by FENG (1978) from the Mapingian of Sichuan, China. The latter, however, differs from the former by absence of dental plates.

Occurrence.-K-2 


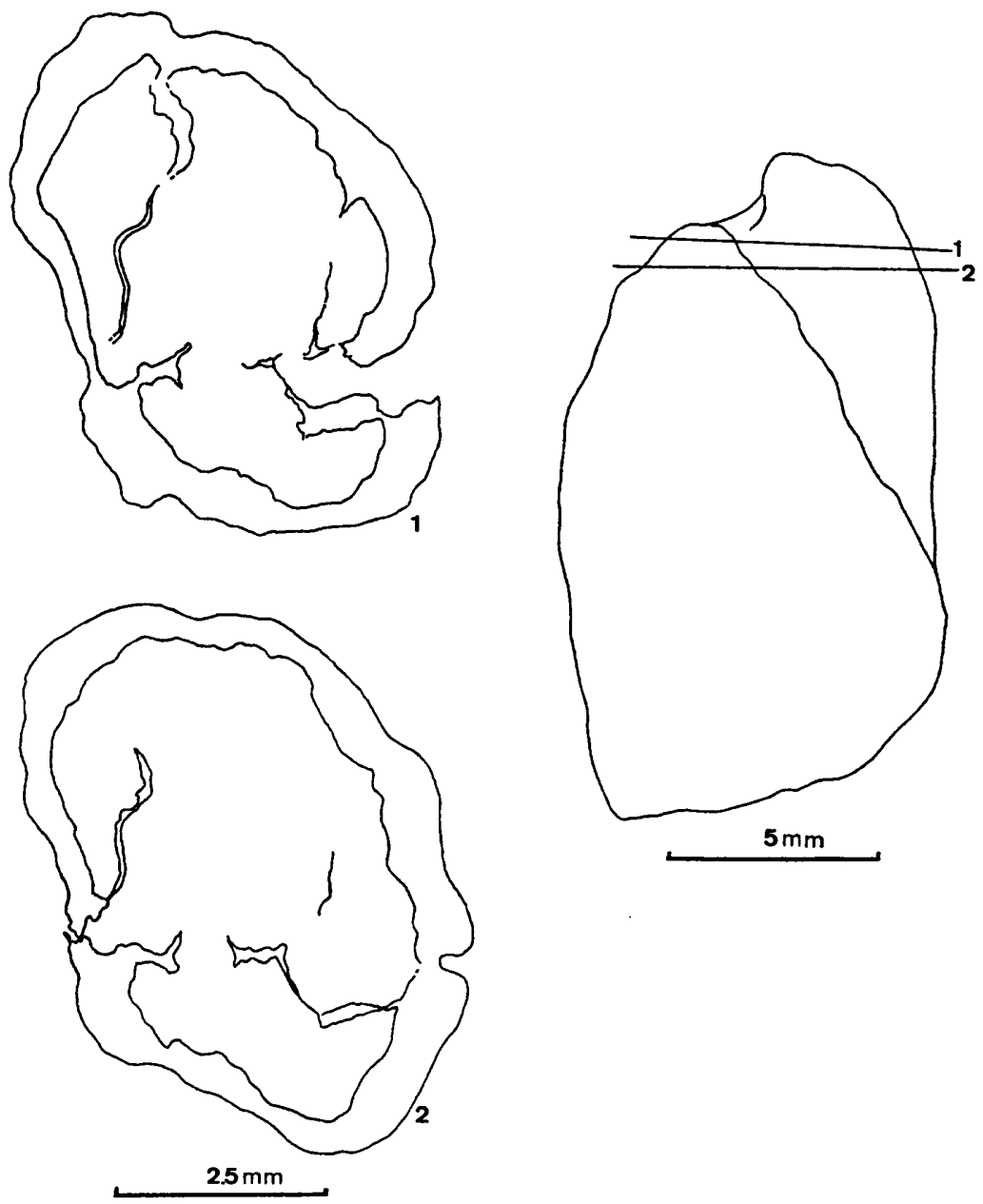

Fig. 4. Pugnacidae gen. and sp. indet. Serial transverse sections of a specimen, GK-D 31603.

Superfamily Stenoscismatacea OEHLERT, 1887

Family Stenoscismatidae OEHLERT, 1887

Subfamily Stenoscismatinae OEHLERT, 1887

Genus Stenoscisma CoNRAD, 1839

Type-species.-Terebratula schlotheimi voN BucH, 1835

Stenoscisma japonica, new species

Pl. 16, Fig. 8; Pl. 17, Figs. 1-3

Material.-Holotype, GK-D 31602 (pl. 17, fig. 1) ; Paratypes, GK-D 31673, (pl. 17, fig. 3), 31671 (pl. 17, fig. 2). Internal structures partly shown by a section of a specimen, GK-D 31647 (Text-fig. 5).

Diagnosis.-Shell small for genus; outline transversely subpentagonal with slightly larger width than length; lateral profile subequally convex; anterior 
profile strongly dorsi-biconvex; broad sulcus and fold discriminated on anterior half with three to four sharp costae on each of them. Internally with ventral spondylium and dorsal camarophorium of moderate height.

Description.-Moderately dorsi-biconvex shell with widest part at midlength or slightly anterior to it. Pedicle valve slightly convex with largest convexity at slightly anterior to beak; beak pointed and shape of pedicle opening unknown; broad sulcus with flat bottom originates at midlength with three to four subangular costae, originating anteriorly at about seven-tenths of length from posterior margin; intercostal grooves sharp with same width to costae; flanks gently convex with completely smooth surface. Brachial valve moderately convex, transverse convexity much larger than longitudinal; fold barely discriminated near anterior margin; subangular costae very short, corresponding to those of opposite valve and normally counted two or three; anterior commissure

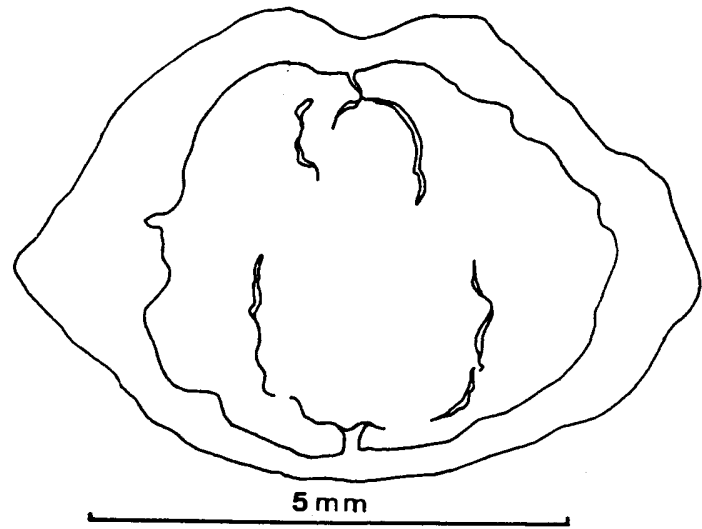

Fig. 5. Stenoscisma japonica, n. sp. A transverse section of a specimen, GK-D 31647.

\section{Explanation of Plate 16}

Figs. 1-4. Nipponirhynchia shutoi, n. gen. and n. sp. ..........Page 163 1a-d. Dorsal, ventral, anterior, and lateral views of the holotype, GK-D 31600 , Loc. $\mathrm{K}-2, \times 1.5$.

2a-d. Dorsal, ventral, anterior, and lateral views of a paratype, GK-D 31646, Loc. K-2, $\times 1.5$.

3-4. Anterior views of two paratypes, respectively GK-D 31655 and 31642, Loc. K-2, respectively $\times 2$ and 1.5

Figs. 5-7. Uncinunellina hayasakai, n. sp. ....................... 166

5a-d. Dorsal, ventral, anterior, and lateral views of a paratype, GK-D 31653, Loc. K-2, $\times 2$.

6a-d. Anterior, dorsal, ventral, and lateral views of a paratype, GK-D 31648 , Loc. K-2, $\times 2$.

7a-d. Ventral, anterior, lateral, and dorsal views of the holotype, GK-D 31644, Loc. K-2, $\times 2$.

Fig. 8. Stenoscisma japonica, n. sp. ............................ 169

8a-d. Lateral, dorsal, ventral, and anterior views of a specimen, GK-D 31647 ,

Loc. $\mathrm{K}-2, \times 2$. 
Mem. Fac. Sci., Kyushu Univ., Ser. D, Vol. XXV

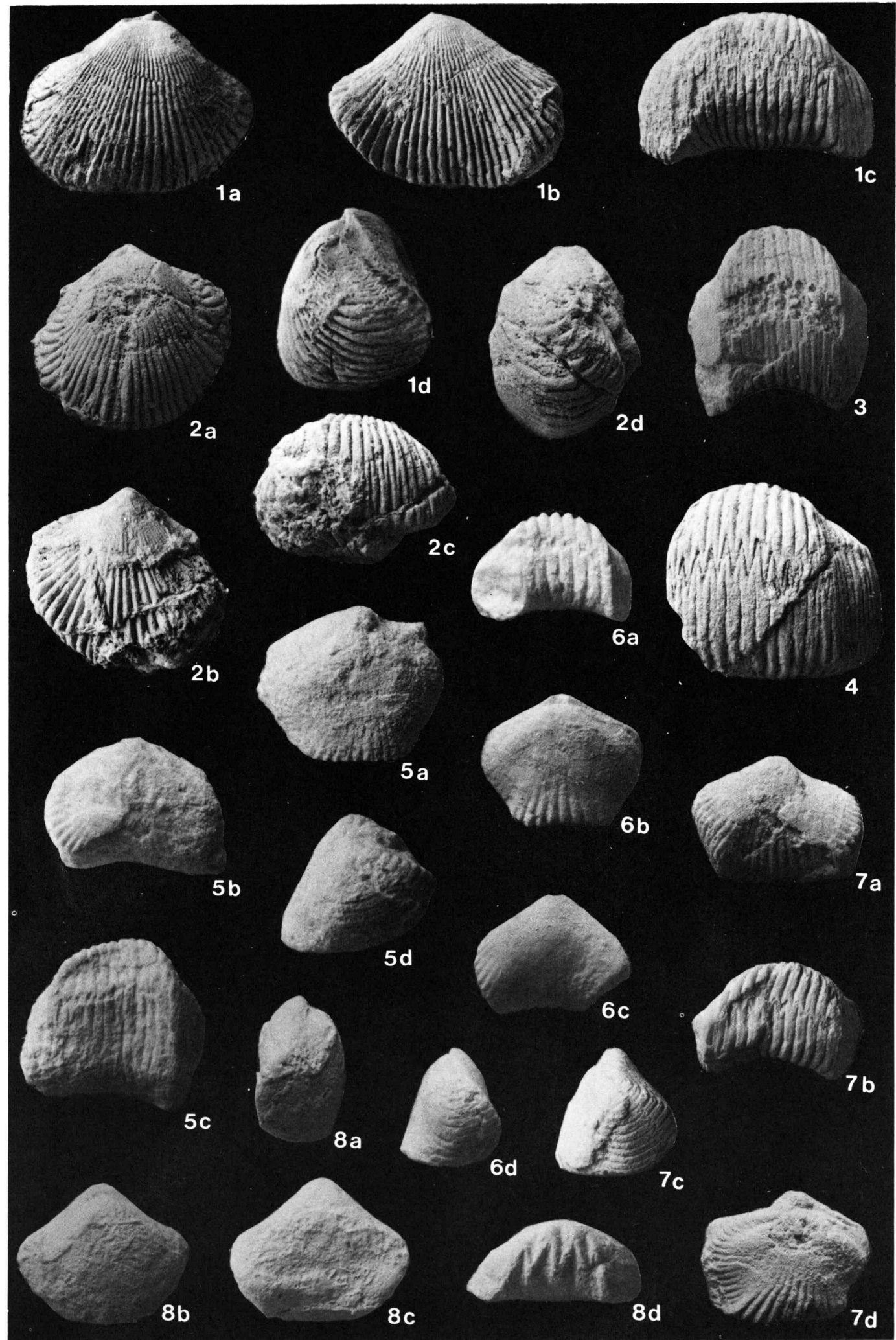

J. Yanagida \& I. Nishikawa: Permian Brachiopods 
Mem. Fac. Sci., Kyushu Univ., Ser. D, Vol. XXV

Plate 17

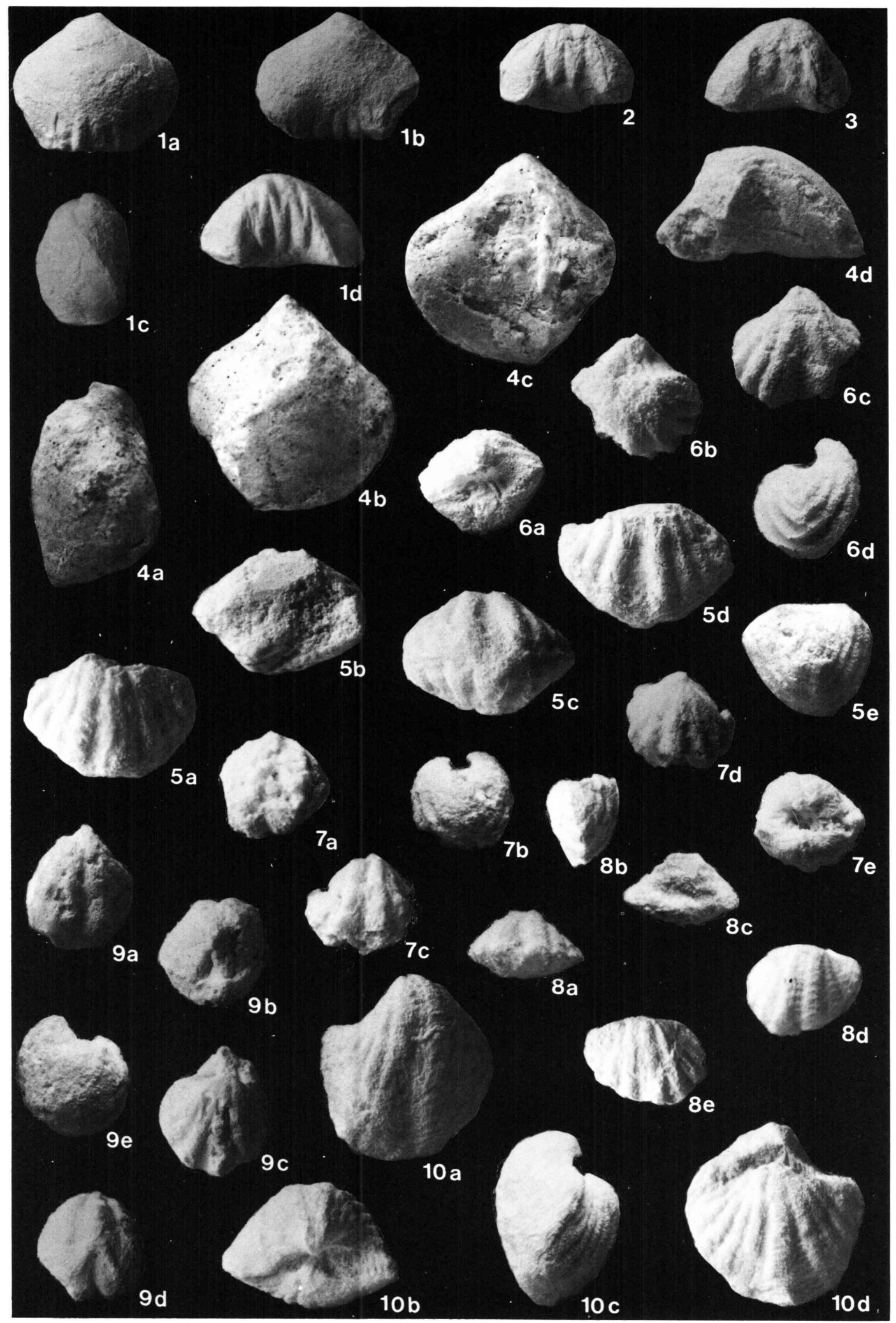

J. Yanagida \& I. Nishikawa: Permian Brachiopods 
strongly uniplicate.

Internal structures only partly known about a wide spondylium with low but stout median septum and a camarophorium. Other structures unknown.

Measurements in $\mathrm{mm}$.

\begin{tabular}{rcccc} 
& length & width & thickness & $\begin{array}{c}\text { number of } \\
\text { costae on fold and } \\
\text { sulcus ( ) }\end{array}$ \\
\hline Holotype (GK-D 31602) & 10.8 & 13.4 & 7.3 & $4(3)$ \\
Paratype (GK-D 31671) & & 10.5 & 7.2 & $3(2)$ \\
Paratype (GK-D 31673) & ca 10 & 11.2 & 6.8 & $3(2)$ \\
(GK-D 31647) & 11.6 & 13.5 & 6.6 & $4(3)$
\end{tabular}

Remarks.-This new species is based on a small material, comprising three nearly complete shells, one incomplete, and a fragmentary specimens. There still remains a doubt whether they are in a stage of adult or juvenile. Neverthless they are nearly same in size and tightly arranged growth lines in some specimens suggest that they may be in stage of adult.

Stenoscisma japonica is characterized by its small size, equidimensionally pentagonal outline with nearly smooth surface. Costae are barely observable on a narrow region near anterior margin of sulcus and fold. Flanks are completely smooth. It resembles $S$. tanankouensis (OZAKI) from the Lower Permian of the Taiyuan Series in Northeast China in its size, slightly transverse, pentagonal outline, completely smooth flanks, and mode of costation. The former differs from this similar species in its having uniformly shorter costae on sulcus and fold, and fewer number of them at anterior margin. Among the figured

\section{Explanation of Plate 17}

Figs. 1-3. Stenoscisma japonica, n. sp. .............................. 169 1a-d. Dorsal, ventral, lateral, and anterior views of the holotype, GK-D 31602, Loc. $\mathrm{K}-2, \times 2$.

2 and 3. Anterior views of two paratypes, respectively GK-D 31671 and 31673 , Loc. $\mathrm{K}-2, \times 2$.

Fig. 4. Pugnacidae gen. and sp. indet. ....................... 168 4a-d. Lateral, dorsal, ventral, and anterior views of a specimen, GK-D 31603, Loc. K-2, $\times 2$.

Figs. 5, 8, and 10. Paraspiriferina sp........................... 172 5a-e. Dorsal, posterior, anterior, ventral, and lateral views of a specimen, GK-D 31625, Loc. K-2, $\times 3$.

8a-e. Anterior, lateral, posterior, ventral, and dorsal views of a specimen, GK-D 31696, Loc. K-2, $\times 3$.

10a-d. Ventral, posterior, lateral, and dorsal views of a specimen, GK-D 31624 , Loc. K-2, $\times 3$.

Figs. 6-7, 9. Callispirina sp. ............................ 173

6a-d. Posterior, dorsal, ventral, and lateral views of a specimen, GK-D 31701, Loc. K-2, $\times 3$.

7a-e. Anterior, lateral, ventral, dorsal, and posterior views of a specimen, GK-D 31612, Loc. K-2, $\times 3$.

9a-e. Ventral, posterior, dorsal, anterior, and lateral views of a specimen, GK-D 31617, Loc. K-2, $\times 3$. 
specimens by BroILI (1916) under the name of Camarophoria purdoni Davidson from the Basleoian of Timor, small juvenile specimens (pl. 11, figs. 19-20) are externally similar to the present specimens. But the former is distinguishable from the latter by the smaller size, more rounded outline, and slightly but plicated flanks.

Occurrence.-K-2

Order Spiriferinida COOPER and Grant, 1976

Suborder Spiriferinidina COOPER and GRANT, 1976

Superfamily Spiriferinacea DAvidson, 1884

Family Paraspiriferinidae CoOPER and Grant, 1976

Genus Paraspiriferina REED, 1944

Type-species.—Spiriferina (Paraspiriferina) ghundiensis REED, 1944

Paraspiriferina species undetermined

Pl. 17, Figs. 5, 8, and 10

Material.-Three small specimens, GK-D 31624 (pl. 17, fig. 10), 31625 (pl. 17, fig. 5), and a juvenile specimen, GK-D 31696 (pl. 17, fig. 8) available under heading.

Descriptive remarks.-Shell small for genus, ventri-biconvex, and transversely to equidimensionally rounded in outline, with widest part slightly anterior to hinge line. Pedicle valve uniformly convex transversely and longitudinally with largest convexity in posterior region; beak slightly incurved over delthyrium; interarea narrow for shell width, slightly concave with relatively narrow delthyrium and its edge in middle; sulcus broad and shallow, originating near beak and occupies about a-third of shell width at anterior margin, with narrow and gently concave bottom; each lateral surface ornamented by 4 to 6 simple costae, each costa broad with rounded crest, shalow intercostal groove, and rounded bottom, sulcus bounding costae strong and much broader than neighbouring costae; micro-ornament consists of very tightly spaced, irregular growth lamellae, forming very thick appearance of valve near anterior margin; anterior commissure slightly uniplicate. Brachial valve gently convex with largest convexity in beak region; fold broad with rounded crest; lateral costae round-topped, much narrower and lower than fold, and countable about 4 to 5 on each lateral surface; intercostal grooves same with those of opposite valve in their character; micro-ornament same with opposite valve, fine spine bases tightly arranged along anterior edge of growth lamella rarely observable near anterior margin. Internal structures almost unknown with suggestion of existence of dental plates.

Measurements of three specimens in $\mathrm{mm}$.

\begin{tabular}{|c|c|c|c|c|c|c|}
\hline \multirow[b]{2}{*}{ (GK-D 31624) } & \multirow{2}{*}{$\begin{array}{c}\text { length } \\
9.9\end{array}$} & \multirow{2}{*}{$\begin{array}{l}\text { width } \\
9+\end{array}$} & \multirow{2}{*}{$\begin{array}{c}\text { thickness } \\
6.5\end{array}$} & \multicolumn{2}{|c|}{$\begin{array}{c}\text { width of sulcus and } \\
\text { fold at anterior } \\
\text { margin }\end{array}$} & \multirow{2}{*}{$\begin{array}{c}\begin{array}{c}\text { width of } \\
\text { hinge } \\
\text { line }\end{array} \\
7.5\end{array}$} \\
\hline & & & & 3.5 & 3.2 & \\
\hline (GK-D 31625) & $7.3+$ & 9 & 6.8 & 3.0 & 2.7 & 7.5 \\
\hline (GK-D 31696) & $5+$ & 6.1 & 3.7 & 2.3 & 1.5 & 3.7 \\
\hline
\end{tabular}


Of three specimens GK-D 31624 and 31625 are probably on a stage of adult because of remarkably tight arrangement of growth lamellae near anterior margin. The remainder may be a juvenile specimen. Although internal structures are unknown they will be undoubtedly referable to a species of Paraspiriferina by their large folds with rounded crests, comparing with adjacent costae, tightly arranged, irregular growth lamellae with sometimes fine spine bases along their anterior margin, and low rounded costae with shallow intercostal grooves. This small species resembles Paraspiriferina gentilis GRANT from the Lower Permian of Ko Muk, Southern Thailand in external configuration, although the growth lamellae seem to be more remarkable in the former.

Occurrence.-K-2

Callispirina COOPER and MUIR-WOOD, 1951

Type-species.-Spiriferina ornata WAAGEN, 1883

Callispirina species undetermined

Pl. 17, Figs. 6, 7 and 9

Material.-Three smal specimens, GK-D 31612 (pl. 17, fig. 7), 31617 (pl. 17, fig. 9), and 31701 (pl. 17, fig. 6) available.

Descriptive remarks.--Shell strongly biconvex with hinge line shorter than largest width, pedicle valve much larger than brachial valve, and elongately subrounded in outline. Pedicle valve strongly convex longitudinally and transversely; beak moderately incurved over broad open delthyrium; interarea narrow, and slightly concave with rounded edges; sulcus broad at anterior margin, originating at beak with flat lateral slope and sharply marked angular bottom with V-shaped anterior profile, and much broader than neighbouring costae; costae narrowly rounded with deep and narrow intercostal grooves, gradually decreasing strength posterolaterally, about 5 costae counted on each lateral slope; shell surface finely ornamented by minute punctae and also regularly and closely arranged growth laminae. Brachial valve with anteriorly high sharp fold; lateral costae similar to those of opposite valve in their nature, counted 4 to 5 on each lateral slope; anterior commissure strongly zigzag in shape. Internal structures unknown.

Measurements of three specimens in $\mathrm{mm}$.

\begin{tabular}{ccccc} 
& length & width & thickness & hinge line \\
\hline (GK-D 31612) & 5.0 & 5.6 & 5.3 & 4.4 \\
(GK-D 31617) & 7.2 & 5.9 & 6.0 & ca 5 \\
(GK-D 31701) & 7.0 & 6.5 & 5.4 & ca 4
\end{tabular}

Present specimens are characterized by their subangularly rotund shape, broad sulcus with narrow bottom, not remarkable fold, comparing with the neighbouring costae, and closely disposed fine punctae. These characters well represent those of Callispirina. One of present specimens, GK-D 31612, externally slightly resembles that of $C$. rotunda CoOPER and GRANT (1976, pl. 705, figs. 66-70) from the Guadalupian Bell Canyon Formation of West Texas in its rotund valves. Another specimen, GK-D 31701, on the other hand, externally 
closely resembles those of $C$. austrina GranT from the Lower Permian of Ko Muk, Southern Thailand. The slight difference between them is that the former is slightly less transverse and has the fewer costae than the latter.

Occurrence.-K-2

Suborder Retziidina Boucot, JoHnson, and Staton, 1964

Superfamily Retziacea WAAGEN, 1883

Family Retziidae WAAGEN, 1883

Genus Hustedia HALL and Clarke, 1893

Type-species.-Terebratula mormoni MARCOU, 1858

Hustedia aff. $H$. ratburiensis WATERHOUSE and PIYASIN, 1970

Pl. 18, Fig. 7

Compare:

1970. Hustedia ratburiensis Waterhouse and PIYASIN. Palaeontographica, vol. 135 (A), p. 138, pl. 23, figs. 15-30.

1970. Hustedia nakornsrii YanAGIDA. Geol. Palaeont. Southeast Asia, vol. 8, p. 79 , pl. 14, fig. 1 .

1976. Hustedia ratburiensis, Grant. Jour. Palaeont., vol. 50, suppl. no. 3, p. 241, pl. 66, figs. 1-69, pl. 67, figs. 51-58.

Material.-A small incomplete, young shell, GK-D 31626, described under heading with following dimension: width, $4.6 \mathrm{~mm}$; length, $5.0 \mathrm{~mm}$; thickness, $2.5 \mathrm{~mm}$; number of costae on brachial valve, 7 ; number of costae on pedicle valve, 8 .

Descriptive remarks.--Small for genus, slightly longer than wide, widest part slightly anterior to midlength; biconvex with pedicle valve much less inflated than brachial valve; ventral beak incomplete but it suggested to be narrow and suberect; foramen not preserved; interarea very narrow; costae strong and broad with rounded crests and broad intercostal grooves, originating at beaks and numbering 8 on pedicle valve and 7 on brachial valve, median dorsal costa extremely narrow and depressed comparing with neighbouring costae, and it presumed that median costa begins at slightly anterior to dorsal beak. Internal structures unknown.

The Japanese species is composed of a young specimen and it is very difficult to understand the specific character precisely. Although the external characters of it strongly suggest that it is very close to the Lower Permian Thailand species, Hustedia ratburiensis WATERHOUSE and PIYASIN from Southearn Thailand, it seems to me that there are some distinct characters from that closest species of Thailand. The Japanese species is characterized by having very few costae. H. ratburiensis, according to WATERHouse and PIYASIN (1970), has 10 to 12 costae on pedicle valve and consequently it has one or two more pairs of costae as compared with the Japanese species. In number of costae the Japanese species resembles Hustedia indica (WAAGEN) from the upper Lower Permian of the Amb Formation, Salt Range. However, the Salt Range species has much more convex valves and the stronger dorsal median costa than the former. 
Very low and depressed dorsal median costa, originating at slightly anterior to the dorsal beak is another important character of the Japanese species and in this point of view it is closely related with $H$. ratburiensis. The difference of strength between median costa and adjoining ones is much larger in the Japanese species than the Thailand one.

Occurrence.-K-2

Order Spiriferida WAAGEN, 1883

Subcrder Athyrididina Boucot, JoHnson and STATON, 1964

Superfamily Athyridacea MCCoY, 1844

Family Athyrididae McCoY, 1844

Subfamily Athyridinae MCCoY, 1844

Genus Composita Brown, 1849

Type-species.-Spirifer ambiguus SOWERBY, 1823

Composita jogensis, new species

Pl. 18, Figs. 1 and 2

Material.-Holotype, GK-D 31608 (pl. 18, fig. 1), Paratypes, GK-D 31611 (pl. 18, fig. 2) and GK-D 31700.

Internal characters shown by serial sections, GK-D 31607. Other ten juvenile specimens also available under heading.

Diagnosis.-Small Composita with slightly uniplicate and rectimarginate commissure, respectively in adult and juvenile stage, and subtrigonally ovate outline with largest width in anterior half of shell; interior with thin dental plates and strong hinge plates.

Description.-Shell small for genus, moderately biconvex; outline subtrigonally ovate with widest part at anterior to midlength; commissure rectimarginate in immature stage and slightly uniplicate in stage of adult, fold only distinguishable near anterior margin with very low and gently arched crest; sulcus shallowly marked near anterior margin; growth lines sometimes well marked along margins of mature specimens.

Pedicle valve evenly convex longitudinally and transversely with largest convexity at beak region; beak short, suberect; foramen subcircular to subovate and smal for genus. Brachial valve strongly convex in posterior half with apex nearly concealed in pedicle valve.

Pedicle valve interior with thin dental plates sometimes fused to inner sides of shell. Brachial valve interior not well preserved, although deep sockets and strong hinge plates easily suggested.

Measurements in $\mathrm{mm}$ and degrees.

\begin{tabular}{lrrrrc} 
& length & $\begin{array}{c}\text { length of } \\
\text { brachial } \\
\text { valve }\end{array}$ & width & thickness & $\begin{array}{c}\text { apical } \\
\text { angle }\end{array}$ \\
\hline Holotype (GK-D 31608) & 12.2 & 11.1 & 10.4 & 7.3 & 74 \\
Paratype (GK-D 31611) & 8.5 & 7.5 & 7.2 & 5.8 & 76 \\
Paratype (GK-D 31700) & 6.5 & 6.0 & 6.4 & 4.3 & 77 \\
(GK-D 31628) & 8.0 & 7.1 & 7.2 & 4.7 & 76
\end{tabular}


Remarks.-This new species, Composita jogensis, is characteristically small for the genus and has subtrigonally ovate outline with the largest width at about two-thirds of the length from beak. It has comparatively narrower apical angle than other known Permian species of Composita. Another character of C. jogensis is in its thin dental plates, frequently fusing to shell wall, nevertheless they are distinguished from shell wall by their dark color.

Among the Permian species of Composita, C. advena Grant from the Lower Permian of Ko Muk, Southern Thailand is close to C. jogensis in its small size

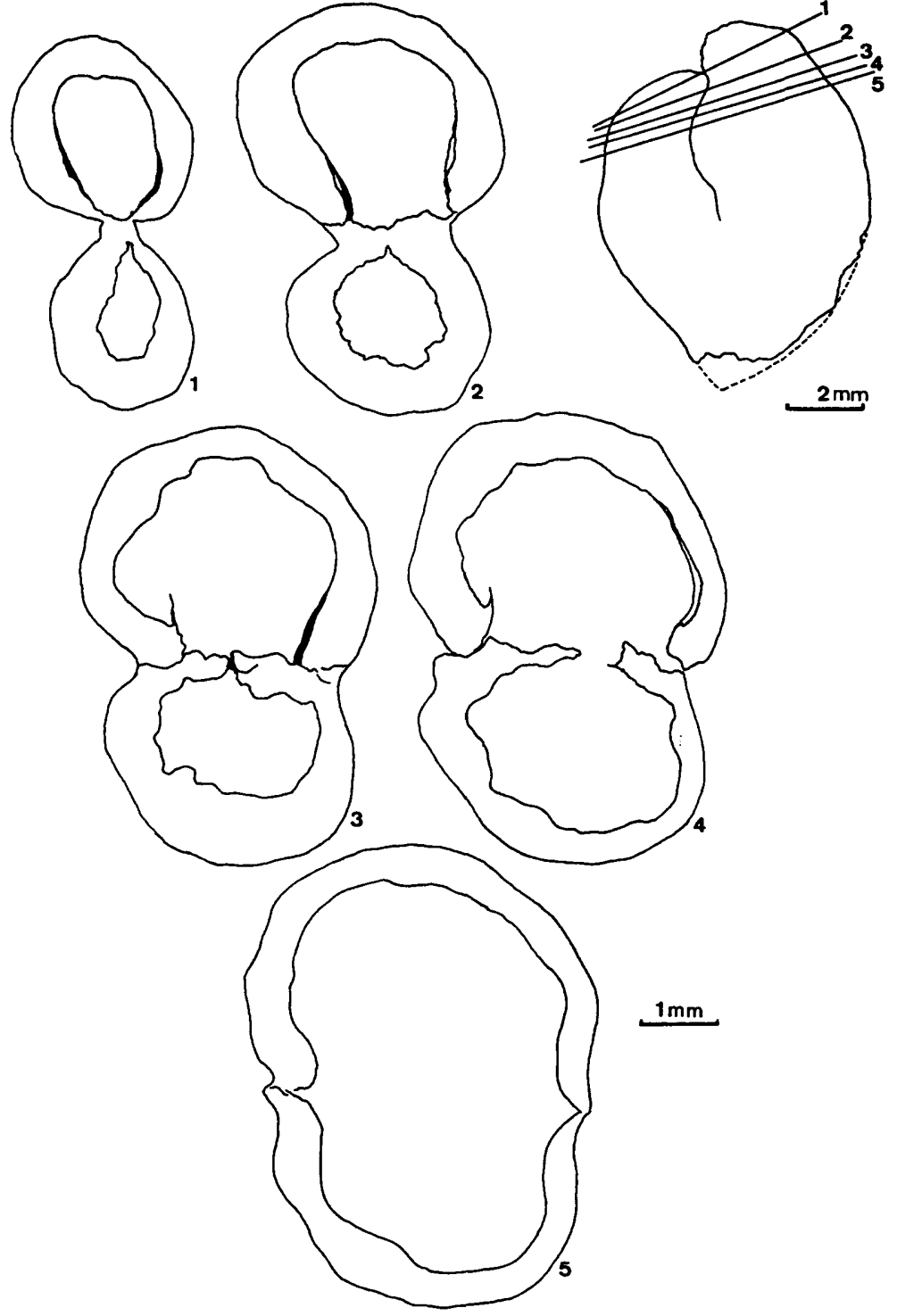

Fig. 6. Composita jogensis, n. sp. Serial transverse sections of a specimen, GK-D 31607. 
and general form. The former, however, is distinct from the latter by having larger apical angles and more folded anterior commissure.

Occurrence.-K-2

Suborder Spiriferidina WAAGEN, 1883

Superfamily Cyrtiacea FrEDERIKS, 1919 (1924)

Family Ambocoeliidae George, 1931

Genus Crurithyris GEORGE, 1931

Type-species.-Spirifer urei FLEMING, 1828

Remarks.-Rounded outline, very narrow interareas with rounded hinge ends, and convex brachial valve of the present specimen strongly recall those of Orbicoelia WATERhouse and PIYAsin (1970) from the Middle Permian of Khao Phrik, Southern Thailand. The only one but decisive character to distinguish the present species from those of Orbicoelia is presence of a faint depression on anterior half of pedicle valve.

\section{Crurithyris sp.}

Pl. 18, Fig. 5

Material.-Only a very small specimen, GK-D 31659, with following dimension is available: width, $4.5 \mathrm{~mm}$; length, $5.6 \mathrm{~mm}$; thickness, $3.3 \mathrm{~mm}$; length of hinge line, $2.4 \mathrm{~mm}$.

Descriptive remarks.-Shell very small for genus, strongly ventri-biconvex,

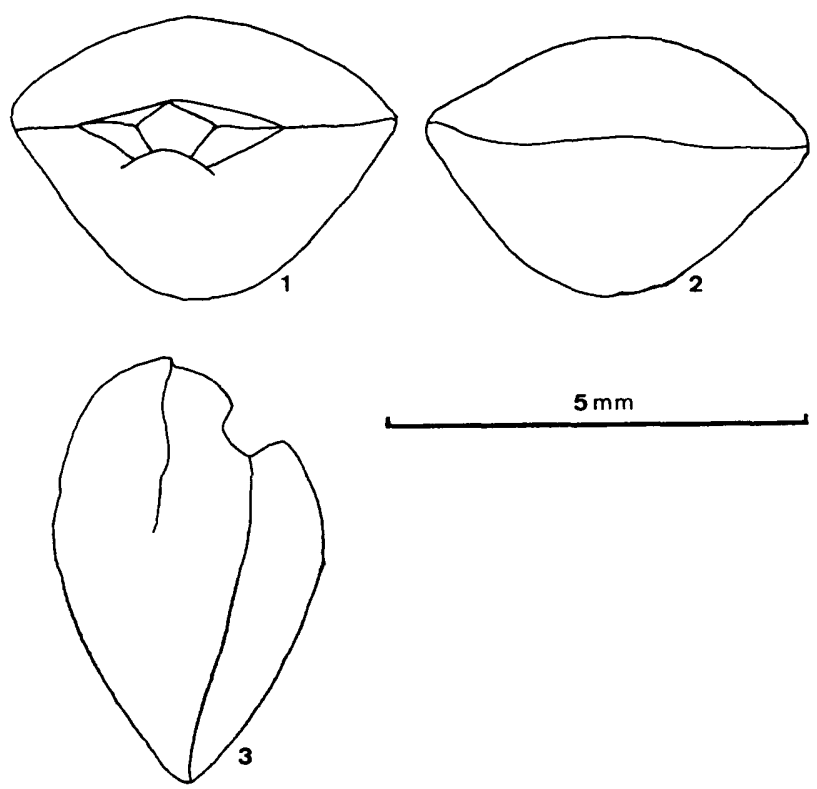

Fig. 7. Crurithyris sp. Posterior, anterior, and lateral views of a specimen, GK-D 31659 , showing large pedicle valve, small interareas, delthyrium and notothyrium, and mode of anterior commissure. 
outline longitudinally subrounded with widest part slightly anterior to midlength; hinge line much shorter than shell width with rounded cardinal extremities. Pedicle valve strongly convex posteriorly with largest convexity in umbonal region; beak short, thick, and moderately incurved; interarea narrow, relatively high, and slightly concave; delthyrium open and triangular with relatively wide basal part, deltidial flanges absent; sulcus represented by a faint depression only recognizable near anterior margin without any trace of emargination at anterior margin; micro-ornament not preserved. Brachial valve much smaller and less convex than opposite valve, although it uniformly convex for genus in profile; beak bluntly pointed with low flat interarea and wide notothyrium. Anterior commissure nearly rectimarginate with a trace of faint dorsal arcuation.

Some external characters, such as very short hinge line and rounded hinge margin, more convex brachial valve than those of other species, and delthyrium without deltidial flanges, seem to exclude this species from Crurithyris. However, a faint but apparent existence of median depression on the pedicle valve and the brachial valve with a short beak are undoubtedly referable to species of Crurithyris. Among known species of Crurithyris, C. tumibilis COOPER and Grant, 1976, from the Lower Permian Gaptank Formation and the Neal Ranch Formation in West Texas is similar to the Japanese species in its outline and tumid brachial valve which is rather rare than normal for the genus. The Japanese species, however, differs from $C$. tumibilis by its longitudinally elongated outline, shorter hinge line, and its proportionately larger brachial valve, comparing with the opposite valve.

Occurrence.-K-2

\author{
Superfamily Reticulariacea WAAGEN, 1883 \\ Family Martiniidae WAAGEN, 1883 \\ Genus Martinia McCoy, 1844 \\ Type-species.-Spirifer glaber SOWERBY, 1820 \\ Martinia nipponica, new species \\ Pl. 18, Figs. 3 and 4
}

Material.-Two small but nearly complete specimens, GK-D 31619, holotype (pl. 18, fig. 4), and GK-D 31662, paratype (pl. 18, fig. 3), described under heading. Posterior part of holotype slightly sectioned to show internal structure.

Diagnosis.-Small Martinia with rounded fold, shallow sulcus, and very weak subsidiary plications on each side of fold near anterior margin.

Description.-Shell small for genus, biconvex; outline transversely subelliptical to suboval with very short hinge line and rounded cardinal margin; widest part at midlength of shell.

Pedicle valve much more convex than brachial valve; beak prominent, moderately incurved over open delthyrium; interarea narrow, relatively high, and slightly concave, a pair of delthyrial flanges along lateral margin of delthyrium; sulcus broad, very shallow, and only traceable near anterior margin; faint folding traceable along commissure from sulcus toward lateral margin, 


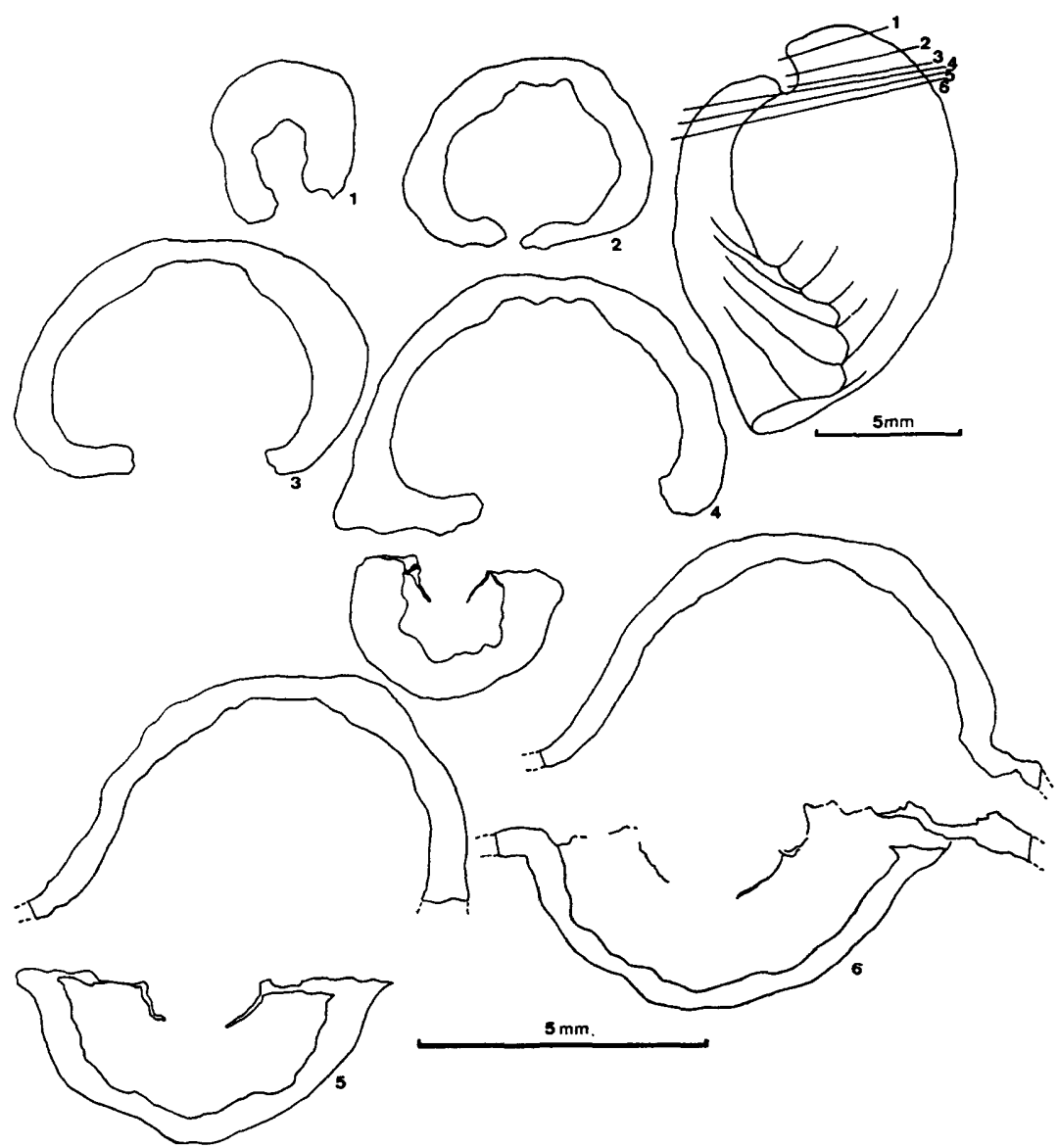

Fig. 8. Martinia nipponica, n. sp. Serial transverse sections of posterior region of the holotype, GK-D 31619.

counting 3 to 4 undulations on each lateral slope. Brachial valve less convex than opposite one; broad fold with rounded crest developes on anterior half, boundary between fold and lateral slope remarkably folded and weak undulation continuous toward lateral margin, making 3 to 4 subsidiary and rudimentary plications on anterior surface of each lateral slope; interarea very low with wide notothyrium; anterior commissure uniplicate or parasulcate.

Measurements in $\mathrm{mm}$ of type specimens.

\begin{tabular}{lcccc} 
& length & width & thickness & hinge line \\
\hline Holotype (GK-D 31619) & 17.1 & 19.6 & 11.4 & 9.6 \\
Paratype (GK-D 31662) & 10.4 & 11.7 & 6.3 & 5.3
\end{tabular}

Pedicle valve interior without dental plates and median septum; muscle areas suggested to be well sculptured in umbonal region by serial sections. Brachial valve interior with small hinge sockets and helicophores extending dorsally from socket ridges in same transverse curveture of brachial valve; other characters unknown. 


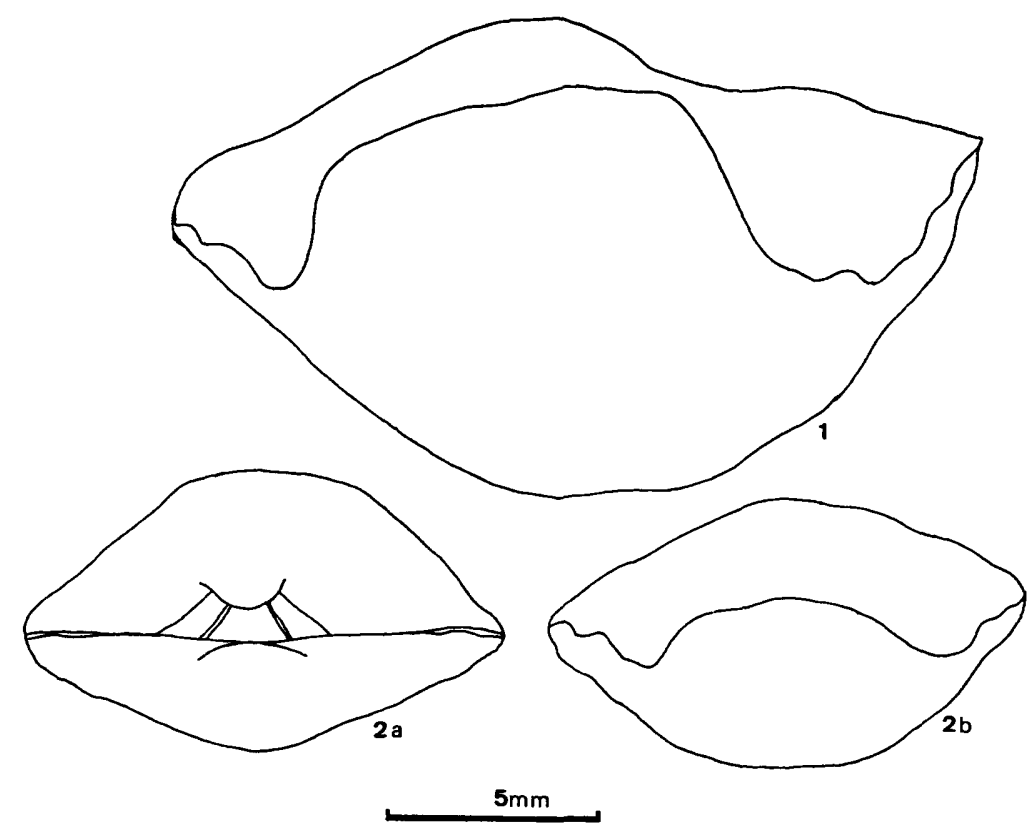

Fig. 9. Martinia nipponica, n. sp. Anterior view of the holotype (1), GK-D 31619 and posterior (2a) and anterior (2b) views of the paratype, GK-D 31662, showing mode of anterior commissure, interarea and delthyrium of pedicle valve.

Remarks.-Martinia nipponica is very unique among species of Martinia by having very weak plications on lateral slopes and a broad remarkable fold. Lateral plications of the holotype are stronger than those of the paratype, juvenile specimen. Nevertheless lateral plications of the holotype are very weak and only recognizable by an effective light. In the paratype specimen they are incipient and are barely recognized by very weak undulation of anterior commissure. In these points of views the Japanese species is most closely related with Martinia warthi WAAGEN and $M$. chidruensis WAAGEN, both from the Permian of the Salt Range. Whereas they are distinguished from $M$. nipponica by their outline with the widest part locating further anterior to that of $M$. nipponica. Fold and sulcus of the Salt Range species are much more remarkably marked than the Japanese one. Lateral plications of $M$. nipponica are stronger than those of $M$. warthi and $M$. chidruensis.

GraNT (1976) described an undetermined martiniid genus and species with distinct costae from the Lower Permian of Ko Muk and Khao Chang, Southern Thailand. It is, however, clearly distinguished from M. nipponica by its globular shape.

Occurrence.-K-1

Genus Elivella Frederiks, 1919 (1924)

Type-species.-Martiniopsis baschkirica TSCHERNYSCHEW, 1902 Elivella aff. E. baschkirica (TSCHERNYSCHEW), 1902

P1. 18, Fig. 6 


\section{Compare:}

1902. Martiniopsis baschkirica TsChernysChew. Mem. Com. Geol., vol. 16, no. 2, pp. 558-559, pl. 63, fig. 1 .

Material.-An incomplete specimen, GK-D 31661, available with following dimension: length, $13.9 \mathrm{~mm}$; width, $13.2 \mathrm{~mm}+$; thickness, $7.0 \mathrm{~mm}$; hinge line, $7.0 \mathrm{~mm}$.

Descriptive remarks.-Shell subrounded, biconvex with pedicle valve more convex than brachial, widest part at midlength, and very short hinge line, about three-fourths of shell-width, with very rounded hinge margin: anterior commissure nearly rectimarginate with very slight central undulation.

Pedicle valve moderately convex posteriorly with elevated and incurved

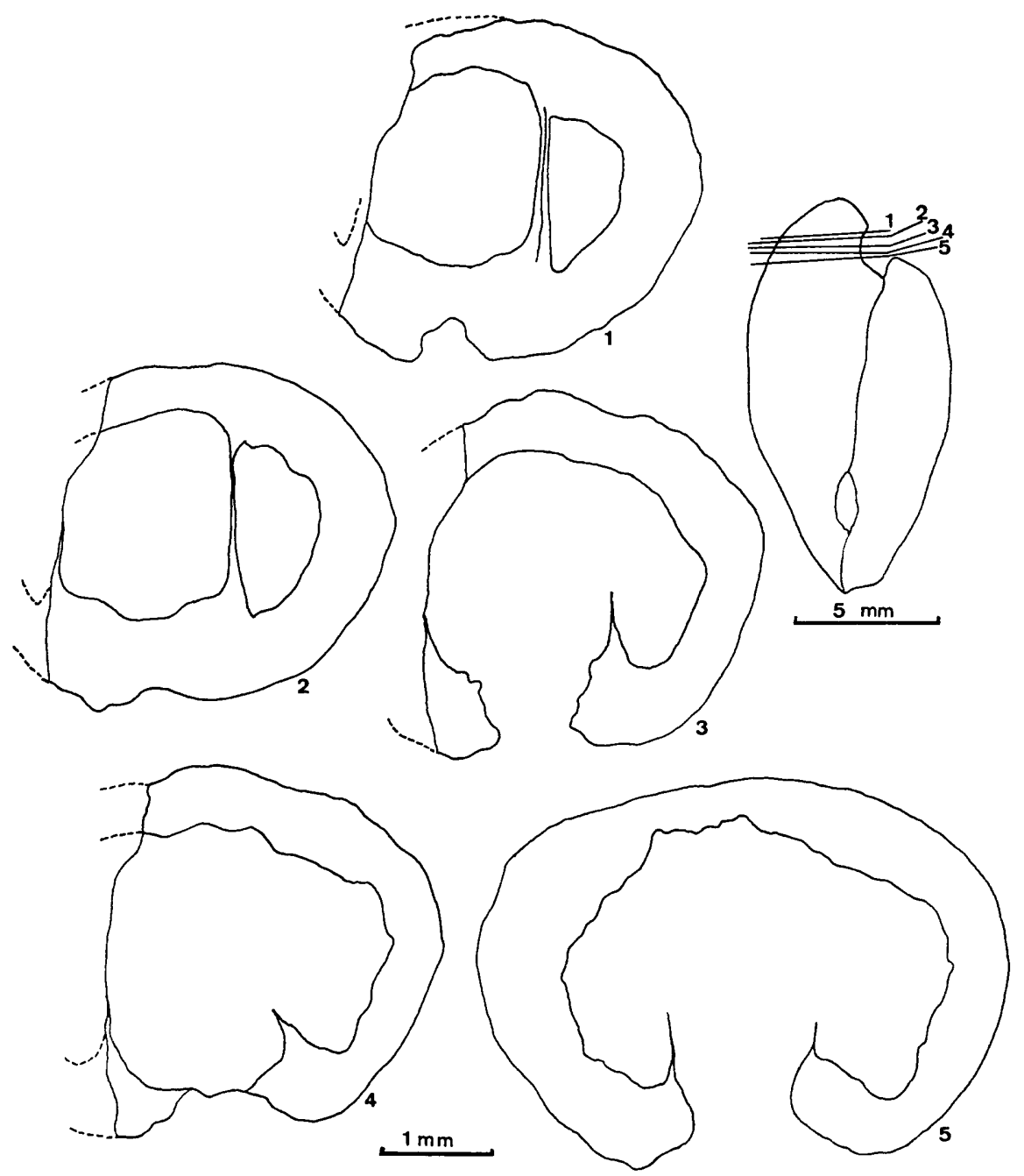

Fig. 10. Elivella aff. E. baschkirica (TSCHERNYSCHEW). Serial transverse sections of a specimen, GK-D 31661. 
beak; interarea rather low and flat; delthyrium narrow and open; sulcus very shallow and narrow, originating in umbonal region; surface ornamented by numerous broad, low rounded costae with very occasional bifurcation, more than 25 costae countable, tightly arranged fine growth lamellae, and very faint capillae barely recognizable under an effective light. Pedicle valve interior with thin, short dental plates reduced to teeth ridges and without median septum.

Brachial valve subrounded, very uniformly and gently convex longitudinally and transversely; fold rudimentarily recognizable at anterior margin; interarea low, flat and inclined on commissural plane; surface ornamented by same elements with pedicle valve.

The Japanese species is represented by a small incomplete specimen and therefore the details of internal and external characters are not understood enough. Nevertheless the following characteristics of it are well in harmony with those of Elivella baschkirica (TSCHERNYSCHEw) from the Lower Permian of the Urals: subrounded outline with weakly convex brachial valve, very short hinge line, slightly less than a half of the largest width, numerous low plications, and fine capillae. The Ural species, however, is slightly different from the Japanese one by having the stronger plications and the more distinct fold and sulcus.

Elivella baschkirica was briefly described by $\mathrm{LI}$ and Gu (1976) from the Upper Carboniferous of Inner Mongolia. The Mongolian species is much different from the Japanese one by its larger shell, more inflated pedicle valve, stronger and fewer plications, and less rounded outline. E. baschkirica was also recorded from the Upper Carboniferous of Liaoning, Northeast China by LI, GU, and SU (1980). The Liaoning species is also distinguished from the Japa-

\section{Explanation of Plate 18}

Figs. 1-2. Composita jogensis, n. sp. .......................... 175 1a-d. Dorsal, lateral, ventral, and anterior views of the holotype, GK-D 31608, Loc. $\mathrm{K}-2, \times 2$.

2a-d. Anterior, dorsal, lateral, and ventral views of a paratype, GK-D 31611, Loc. K-2, $\times 2$.

Figs. 3-4. Martinia nipponica, n. sp. ............................ 178

3a-e. Dorsal, anterior, posterior, ventral, and lateral views of a paratype, GK-D 31662, Loc. K-2, $\times 2$.

4a-d. Anterior dorsal, ventral, and lateral views of the holotype, GK-D 31619, Loc. K-2, $\times 1.5$.

Fig. 5. Crurithyris sp...................................... 177 5a-c. Dorsal, ventral, and lateral views of a specimen, GK-D 31659, Loc. K-2, $\times 4$.

Fig. 6. Elivella aff. E. baschkirica (Tschernyschew) .............Page 180 6a-d. Posterior, dorsal, ventral, and lateral views of a specimen, GK-D 31661, Loc. $\mathrm{K}-2, \times 2$.

Fig. 7. Hustedia aff. $H$. ratburiensis Waterhouse and PIYASIN .....Page 174 7a-d. Ventral, dorsal, posterior, and lateral views of a specimen, GK-D 31626, Loc. K-2, $\times 4$.

Fig. 8. Purdonella sp. ................................... 190 8a-c. Dorsal, lateral, and ventral views of a specimen, GK-D 31707, Loc. K-1, $\times 1$. 


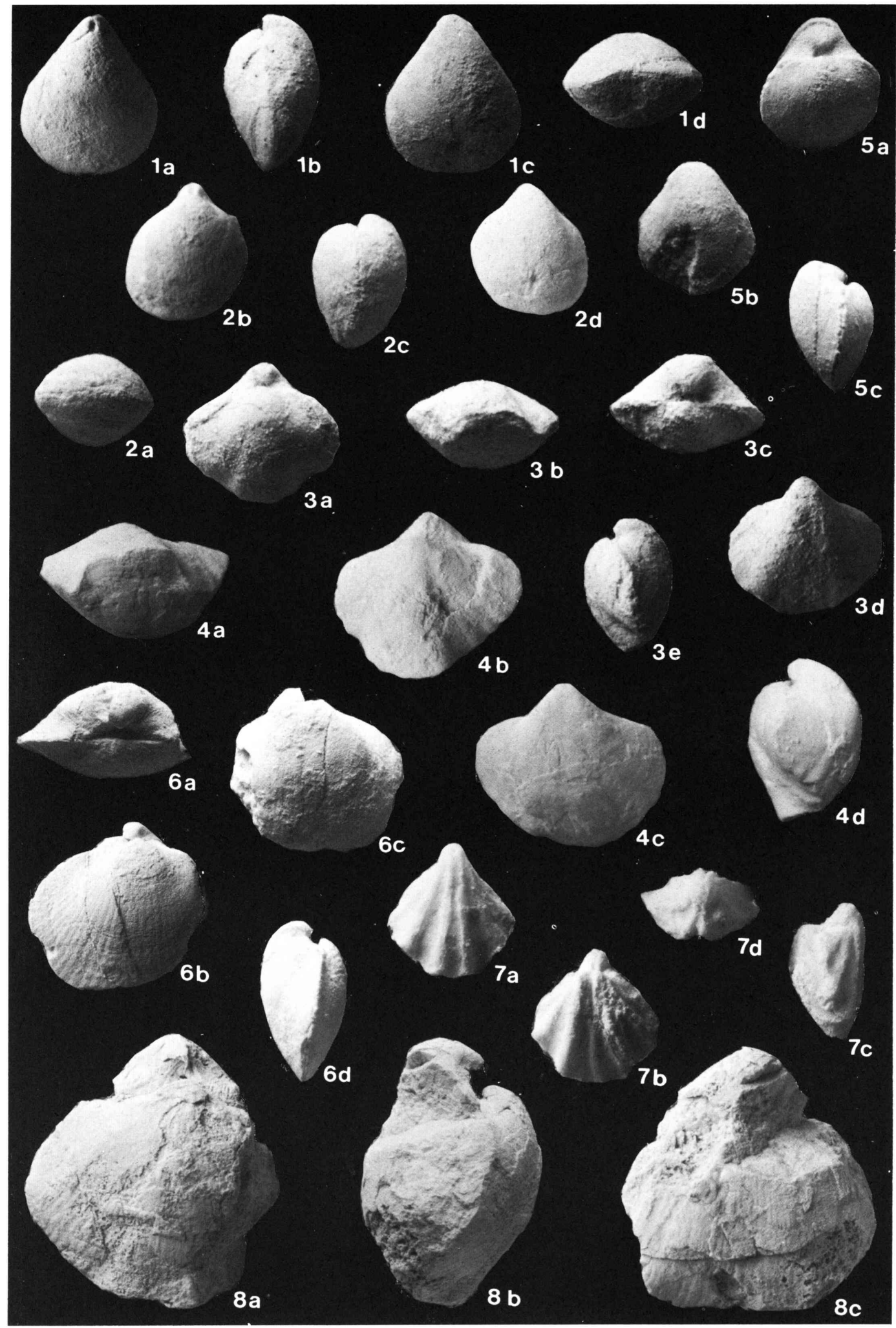

J. YANAGIDA \& I. Nishikawa: Permian Brachiopods 


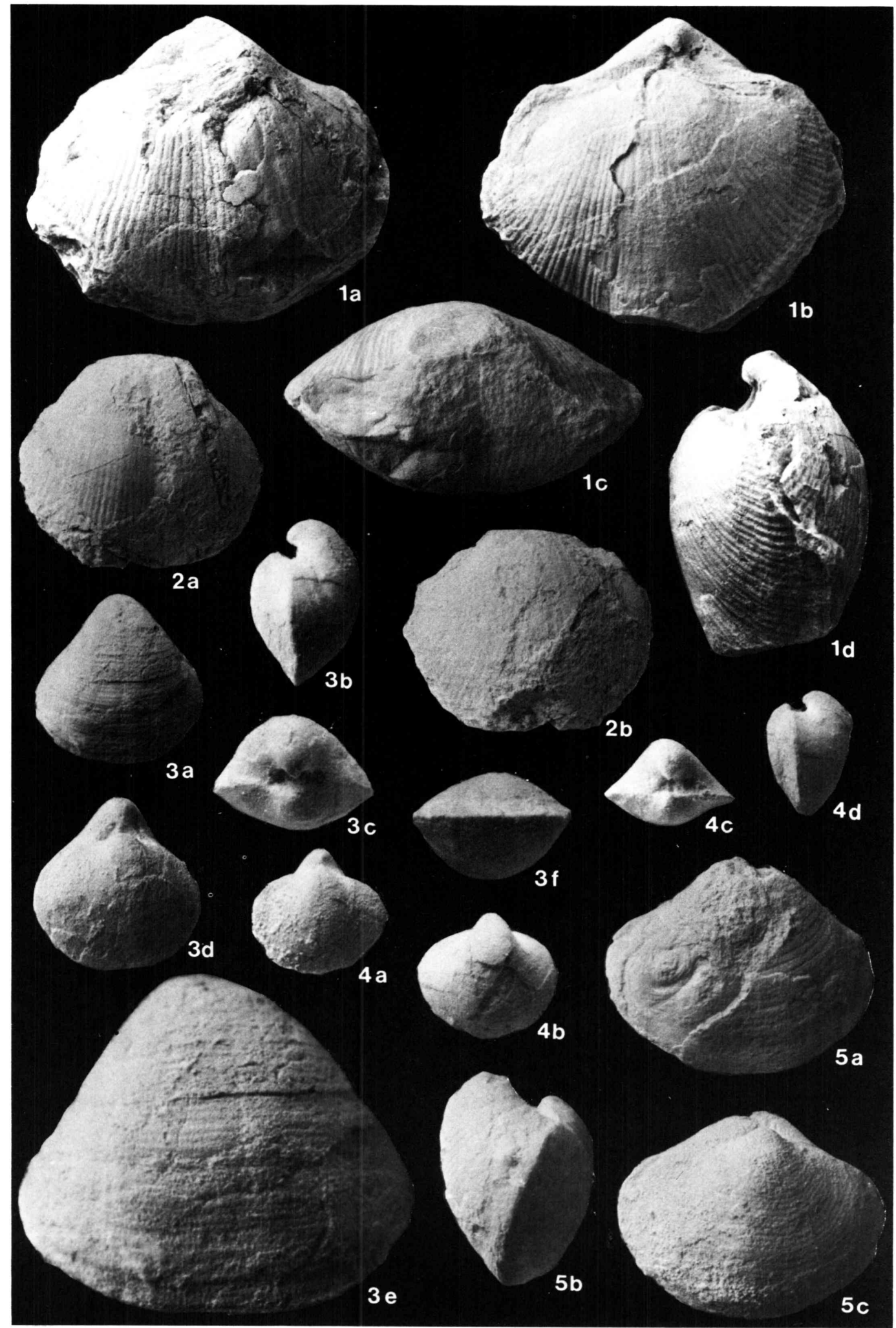

J. Yanagida \& I. Nishikawa: Permian Brachiopods 
nese one by having the larger shell and the stronger plications.

Occurrence.-K-2

Family Elythidae FrEDERIKS, 1919 (1924)

Genus Neophricadothyris LICHAREW, 1934

Type-species.-Squamularia asiatica CHAO, 1929

Remarks.-PAVLOVA (1965) doubted the distinctness of Neophricadothyris from Phricodothyris because characteristics of spiralia of Squamularia asiatica CHAO, the type species of Neophricadothyris, were not examined by CHAO.

COOPER and Grant (1976) discussed Neophricadothyris and they held that the generic concept of Neophricadothyris is valid. According to COOPER and GRANT (1976) coiling axes of spiralia extend posterolaterally and dorsoventrally. The Japanese species under consideration has spiralia of which coiling axes apparently extend posterolaterally toward lateral margin of hinge line. In this point of view it is distinct from that of Phricodothyris of which the coiling axes extend laterally toward lateral margin. It is also distinguished from that of Permophricodothyris which is characterized by its long, numerously coiled, and nearly posteriorly extended spiralia.

\section{Neophricadothyris kawaiensis, new species \\ Pl. 19, Figs. 3 and 4}

Material.-Holotype, GK-D 31620 (pl. 19, fig. 3) ; Paratype, GK-D 31634 (pl. 19, fig. 4). Arrangement of spiralia shown by serial longitudinal sections of a specimen, GK-D 31621. Other internal structures briefly shown by serial sections of a specimen, GK-D 31637. Other 5 specimens also available.

Diagnosis.-Small, nearly equidimensional Neophricadothyris with elevated beak and rectimarginate anterior commissure.

Description.-Shell small for genus, normally ventribiconvex; outline suboval with nearly isometric width and length, hinge line very short, less than a half of width, greatest width at midlength or slightly anterior to it; com-

\section{Explanation of Plate 19}

Fig. 1. Purdonella sadai, n. sp. ...................................... 188

1a-d. Ventral, dorsal, anterior, and lateral views of the holotype, GK-D 31618, Loc. K-2, $\times 1$.

Fig. 2. Purdonella sp. ...................................... 190

2a-b. Ventral and dorsal views of a specimen, GK-D 31630, Loc. K-2, $\times 1$.

Figs. 3-4. Neophricadothyris kawaiensis, n. sp. .................... 183

3a-d, f. Ventral, lateral, posterior, dorsal, and anterior views of the holotype, GK-D 31620 , Loc. K-2, $\times 2$.

3e. Enlarged ventral view of the holotype, showing fine ornament, $\times 4.5$.

4a-d. Dorsal, ventral, posterior, and lateral views of the paratype, GK-D 31634 , Loc. K-2, $\times 2$.

Fig. 5. Neophricadothyris aff. N. catatona CoOPER and GRANT .....Page 186 5a-c. Ventral, lateral, and dorsal views of a specimen, GK-D 31623, Loc. K-2, $\times 2$. 
missure rectimarginate; neither sulcus in pedicle valve nor fold in brachial valve present; concentric growth lines tightly arranged, about 4 in $1 \mathrm{~mm}$ at about 2 $\mathrm{mm}$ posterior to anterior margin, each line with a row of finely disposed spine bases, rarely showing somewhat biramous structure with longitudinally densely arranged microsculpture.

Pedicle valve strongly convex both longitudinally and transversely, convexity normally stronger on posterior half than anterior; umbonal region elevated with incurved beak; interarea narrow, poorly distinguished; delthyrium open, narrowly wedge shaped, lateral margins with very low deltidial flanges. Brachial valve less convex anteriorly; beak short, pointed; interarea slightly concave, subparallel to commissural plane; notothyrium broad.
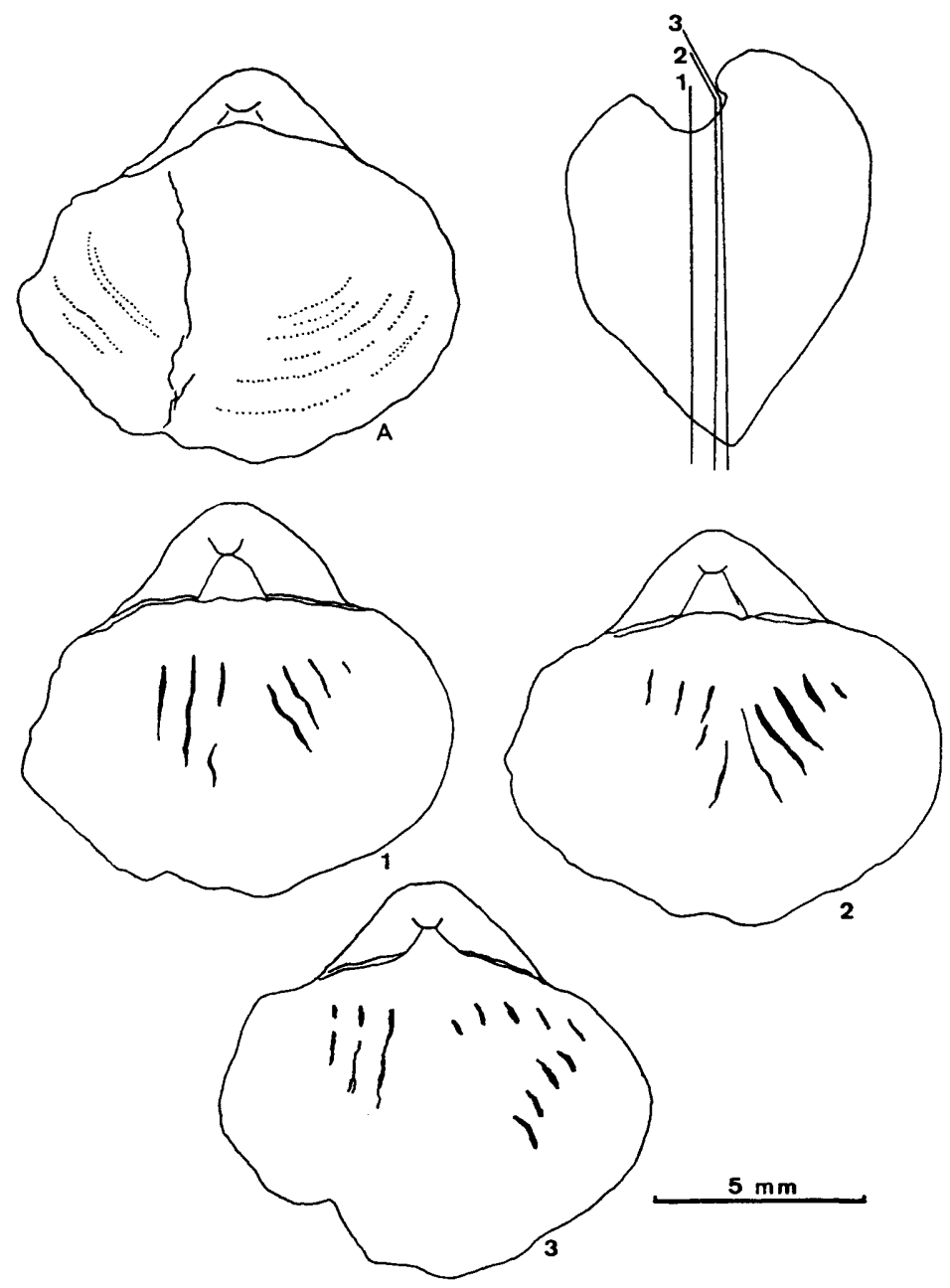

Fig. 11. Neophricadothyris kawaiensis, n. sp. Dorsal view (A) and longitudinal serial sections of a specimen, GK-D 31621, showing arrangement of spiralia and trend of spiral cones. 
Measurements of type specimens in $\mathrm{mm}$.

\begin{tabular}{|c|c|c|c|c|c|}
\hline & length & width & thickness & $\begin{array}{l}\text { length } \\
\text { of } \\
\text { hinge } \\
\text { line }\end{array}$ & $\begin{array}{c}\text { length of } \\
\text { basal part } \\
\text { of } \\
\text { delthyrium }\end{array}$ \\
\hline Holotype (GK-D 31620) & 13.0 & 12.3 & 8.4 & 6.2 & 3.0 \\
\hline Paratype (GK-D 31634) & 9.2 & 9.8 & 6.2 & 4.5 & 1.5 \\
\hline
\end{tabular}

Internal structures only partly confirmed on character of spiralia of brachial valve, coiling axes extend dorsoventrally and diverge posterolaterally, each spiralium with at least 5 coils.

Remarks.-The Japanese species is characterized by uniformly small size, rectimarginate anterior commissure, erected umbo with incurved beak, and posterolaterally extended spiralia. The paratype specimen and the longitudinally sectioned one are probably in immature stage of growth because of very few number, about 5 in each of them, of coilings of spiralia. The holotype specimen, however, may be in adult. Because growth lines are rather tightly arranged in marginal region than posterior.

The present species externally resembles Phricodothyris rostrata (KUTORGA) and P. pyriformis PAVLOVA, respectively from the Lower Permian Schwagerina horizon of the Urals and the Lower Permian Artinskian of the same province (PAVLOVA, 1969).

$P$. rostrata is also reported from the Sakmarian to Artinskian and the Upper Carboniferous of USSR and the Lower Permian Maping Limestone of Kweichou, South China. The marked external difference is the much larger size of $P$. rostrata than Neophricadothyris. Although $P$. rostrata strongly resembles $N$. kawaiensis in its shape, it is clearly distinguished from the latter by its character of the brachial apparatus. Spiral cones were briefly exhibited by PAVLOVA (1969) and transversely extended characters were shown by serial sections (p. 92, fig. 57) and in picture (pl. 7, fig. 7). The figured specimen from

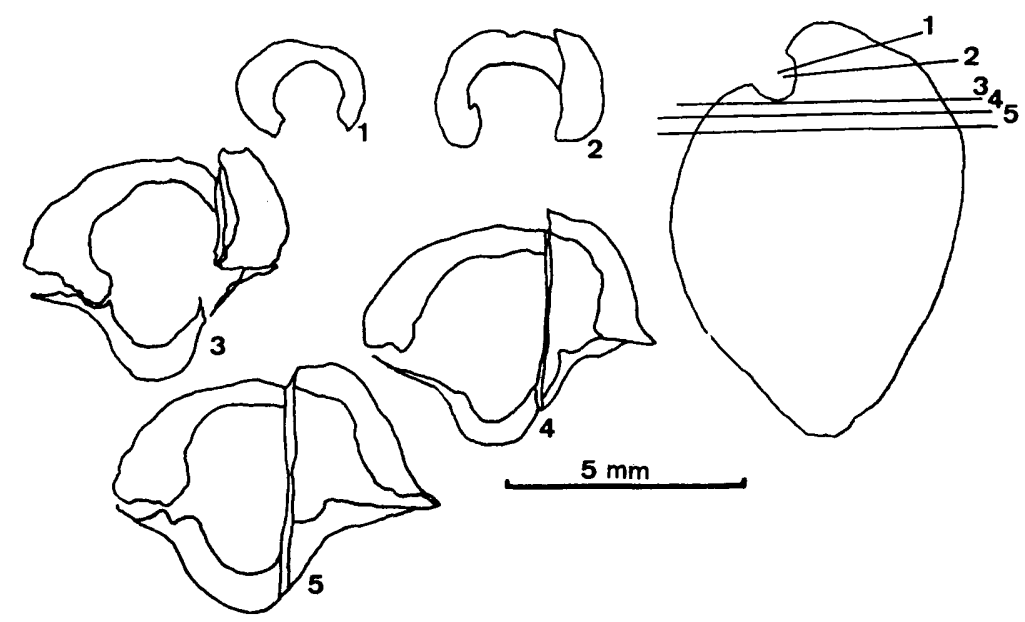

Fig. 12. Neophricadothyris kawaiensis, n. sp. Serial transverse sections of a specimens, GK-D 31637. 
the Lower Permian Maping Limestone of Kweichou, South China by GrabaU (1934, pl. 18, fig. 7) is similar to the present specimens in shape and size. Unfortunately, however, there is no description on spiralia. Consequently the Chinese species was distinguished from the Japanese one, remaining, however, the possibility of congeneric with Neophricadothyris.

Neophricadothyris kawaiensis is also clearly distingushed from Phricodothyris pyriformis PAVLOVA by its markedly smaller size and by having a pair of posterolaterally extended spiralia. Those of $P$. pyriformis extend transversely or slightly posteriorly (PAvlova, 1969, pl. 8, fig. 3).

Occurrence.-K-2

Neophricadothyris aff. N. catatona COOPER and GRANT, 1976

Pl. 19, Fig. 5; Pl. 20, Figs. 1 and 3

\section{Compare.-}

1976. Neophricadothyris catatona Cooper and Grant. Smith. Contr. Paleobiol., no. 21 , p. 2250 , pl. 636 , figs. $1-28$,

Material.-Four incomplete specimens, three articulated valves and a pedicle one, two juvenile and two adult specimens, available under heading.

Descriptive remarks.-Shell medium for genus, moderately biconvex; outline transversely strongly suboval with largest width slightly anterior to midlength; anterior commissure weakly uniplicate; hinge line much shorter than width, about three-fifths of it; fold indistinct; sulcus shallowly rounded, beginning at about midlength, only recognizable on anterior half as slight depression; concentric lamellae tightly and regularly arranged, about 7 and 9 , respec-
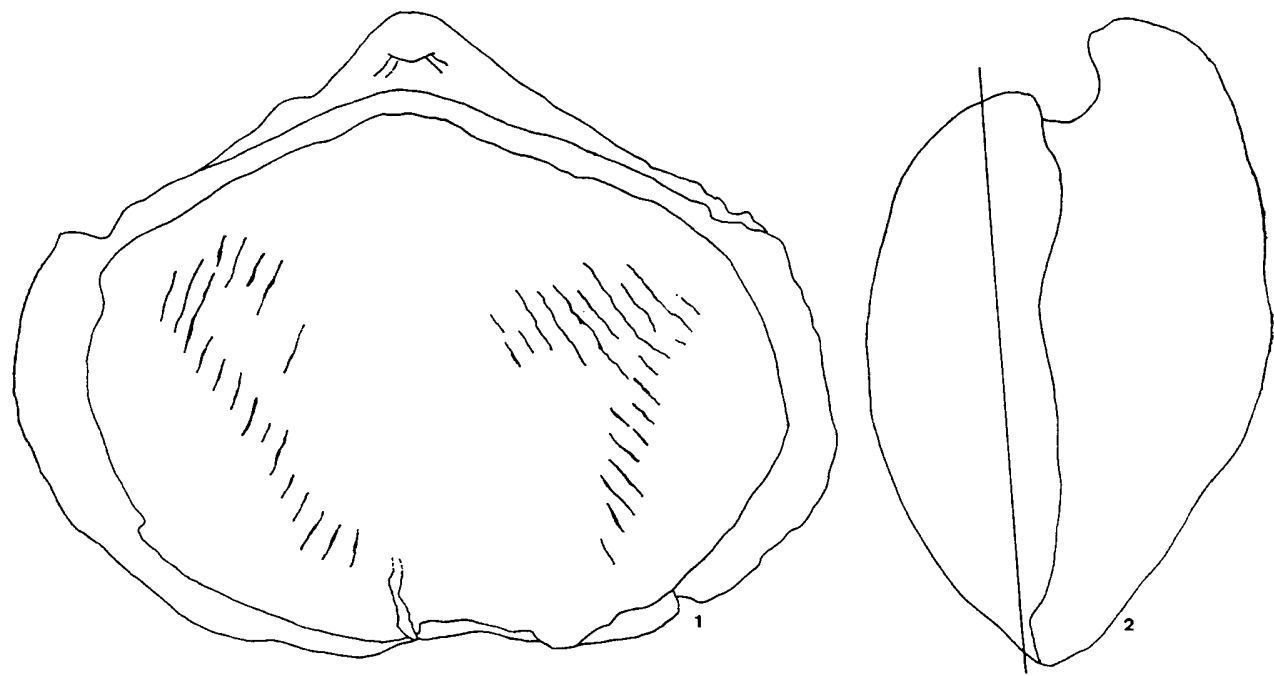

$1 \mathrm{~cm}$

Fig. 13. Neophricadothyris aff. N. catatona CoOPER and GRANT. A longitudinal section of a specimen, GK-D 31638, showing arrangement of spiralia and trend of spiral cones. 
tively in adults and juveniles, in distance of $5 \mathrm{~mm}$ at slightly posterior to median anterior margin; micro-sculptures on each lamella rarely preserved as row of minute, rounded spine bases on exfoliated ones, generally showing row of longitudinal striae, detailed characters of spine bases unknown.

Pedicle valve moderately convex with slightly incurved beak; interarea narrow, relatively indistinct; delthyrium high and wide, deltidial flanges rarely partly preserved. Brachial valve less convex than opposite valve, uniformly convex both longitudinally and transversely; beak short, slightly incurved on basal part of delthyrium. Internal structures only recognizable on spiralia of brachial valve. Spiralia stout, widely coiled anteromedianly with spiral axes extending posterolaterally toward hinge margins, each spiralium counted more than 13 coils.

Measurements of three specimens in $\mathrm{mm}$.

\begin{tabular}{lccccc} 
& length & width & thickness & $\begin{array}{c}\text { length of } \\
\text { hinge line }\end{array}$ & $\begin{array}{c}\text { width of } \\
\text { delthyrium }\end{array}$ \\
\hline (GK-D 31638) & 32.5 & 40.0 & 19.5 & 24.0 & ca 8 \\
(GK-D 31623) & ca 16 & 19.5 & 11.3 & 13.5 & 3.3 \\
(GK-D 31710 & 23.5 & $26+$ & ca 11 & ca 15 & 8
\end{tabular}

The Japanese species under consideration is characterized by its transverse outline with very weak sulcus in anterior half of pedicle valve and very strong, posterolaterally extended spiralia. External characters of it are very similar to Neophricadothyris catatona COOPER and GRANT from the Lower Permian Wolfcampian of West Texas, although the former species is distinct from the latter by its smaller size and much less remarkable sulcus. The Texas species has strongly uniplicate commissure.

Occurrence.-K-2

Neophricadothyris ? species undetermined Pl. 20, Fig. 2

Material.-Single specimen, GK-D 31622, with following dimension available; length, $17.5 \mathrm{~mm}$; width, ca $20 \mathrm{~mm}$; thickness, $12.5 \mathrm{~mm}$; length of hinge line, $14.5 \mathrm{~mm}$; width of delthyrium, ca $5.5 \mathrm{~mm}$.

Descriptive remarks.-Shell small for genus, strongly ventribiconvex; outline moderately transverse, widest part near midlength of pedicle valve; commissure seems to be rectimarginate without fold and sulcus; concentric lamellae fine and regular, countable about 5 in distance of $2 \mathrm{~mm}$ at about $5 \mathrm{~mm}$ posterior to median anterior margin, each lamella ornamented by finely disposed longitudinal striae on exfoliated, slightly inner layer; characters of spine bases unknown.

Pedicle valve much larger than brachial valve in size and convexity with largest convexity and strongly incurved beak in umbonal region; interarea narrow, slightly concave; beak ridges indistinct; delthyrium relatively wide and high. Brachial valve extremely small in convexity comparing with opposite 
valve, very transverse in outline; beak small and suberect. Internal characters unknown.

Generic identification of the present species is questionable because of the evidence of strongly inflated posterior half of pedicle valve. Laterally elongated form of brachial valve suggests that spiralia extend transversely. If so, then both Phricodothyris and Neophricadothyris are considered to be identifiable as the possible genera. However, strongly inflated pedicle valve suggests another possibility of spiralia of which axes extend dorsoventrally and posteriorly with the typical character of Permophricodothyris.

Occurrence.-K-2

\author{
Superfamily Spiriferacea KING, 1846 \\ Family Brachythyrididae FrEDERIKS, 1919 (1924) \\ Genus Purdonella REED, 1944 \\ Type-species.-Spirifer nikitini TSCHERNYSCHEW, 1902 \\ Purdonella sadai, new species \\ Pl. 19, Fig. 1
}

Material.-Holotype, GK-D 31618 (pl. 19, fig. 1), Paratype, GK-D 31629. Other four incomplete specimens also available.

Diagnosis.-Shell large for genus; slightly wider than long with largest width at midlength of shell; cardinal extremities strongly rounded; interarea slightly concave, relatively low and tightly denticulated; costae normally bifurcate anteriorly and rarely trifurcate; pedicle valve interior with short, thin dental plates diverging ventrally.

Description.--Shell uniformly biconvex; outline transversely subelliptical; greatest width at midlength; hinge line much shorter than width; dorsal fold and ventral sulcus broadly developed anteriorly with conspicuously uniplicate anterior commissure in adult stage, but uniplicate anterior commissure slightly developed in juveniles.

Pedicle valve uniformly convex both transversely and longitudinally with strongly incurved beak; hinge line much shorter than shell-width, slightly less than two-thirds of shell-width; interarea weakly concave and apsacline, relatively low comparing to its width and finely ornamented by denticular ridges, about 6 to 7 in $5 \mathrm{~mm}$; delthyrium moderately high for width of its basal part, about a-sixth of width of interarea; cardinal extremities strongly obtuse with rounded appearance; sulcus may broadly originate on posterior half with very shallow depression, anteriorly increases its width and depth with weak anterior prolongation; surface ornamented by low rounded costae with flat crest, bifurcation very common and normally occurs on later stage of growth and costae rarely trifurcate especially near bottom of sulcus, about 8 to 9 costae countable near anterior margin in distance of $1 \mathrm{~cm}$, and more than 20 on anterior surface of sulcus.

Brachial valve with obtusely incurved beak; dorsal interarea unknown; fold broad, indistinguishable from lateral slopes in younger stages but it easily distinguishable on anterior half of valve with individual variation, strength and 
mode of anterior increment of costae same with those of opposite valve, but a strong costa or bifurcated conspicuous costae along middle of crest of fold seem to present, although detailed character unknown owing to strong exfoliation; slight variation recognized on shape of uniplicate anterior commissure, that of holotype has highly but broadly folded median part, paratype, on other hand, has sharper crest.

Pedicle valve interior with thin short dental plates, converging dorsally. Other internal structures unknown.

Measurements of type specimens in $\mathrm{mm}$.

\begin{tabular}{|c|c|c|c|c|c|c|c|}
\hline & $\begin{array}{l}\text { length } \\
\text { of } \\
\text { pedicle } \\
\text { valve }\end{array}$ & $\begin{array}{c}\text { length } \\
\text { of } \\
\text { brach. } \\
\text { valve }\end{array}$ & width & $\begin{array}{l}\text { hinge } \\
\text { line }\end{array}$ & $\begin{array}{l}\text { height } \\
\text { of } \\
\text { inter- } \\
\text { area }\end{array}$ & $\begin{array}{l}\text { width } \\
\text { of } \\
\text { delthy- } \\
\text { rium }\end{array}$ & $\begin{array}{l}\text { thick- } \\
\text { ness }\end{array}$ \\
\hline Holotype (GK-D 31618) & 48.4 & 39.6 & 55.5 & 34.5 & 6.5 & 6.0 & 29.5 \\
\hline Paratype (GK-D 31629) & $43+$ & ca43 & $61+$ & ca43 & & & 35 \\
\hline
\end{tabular}

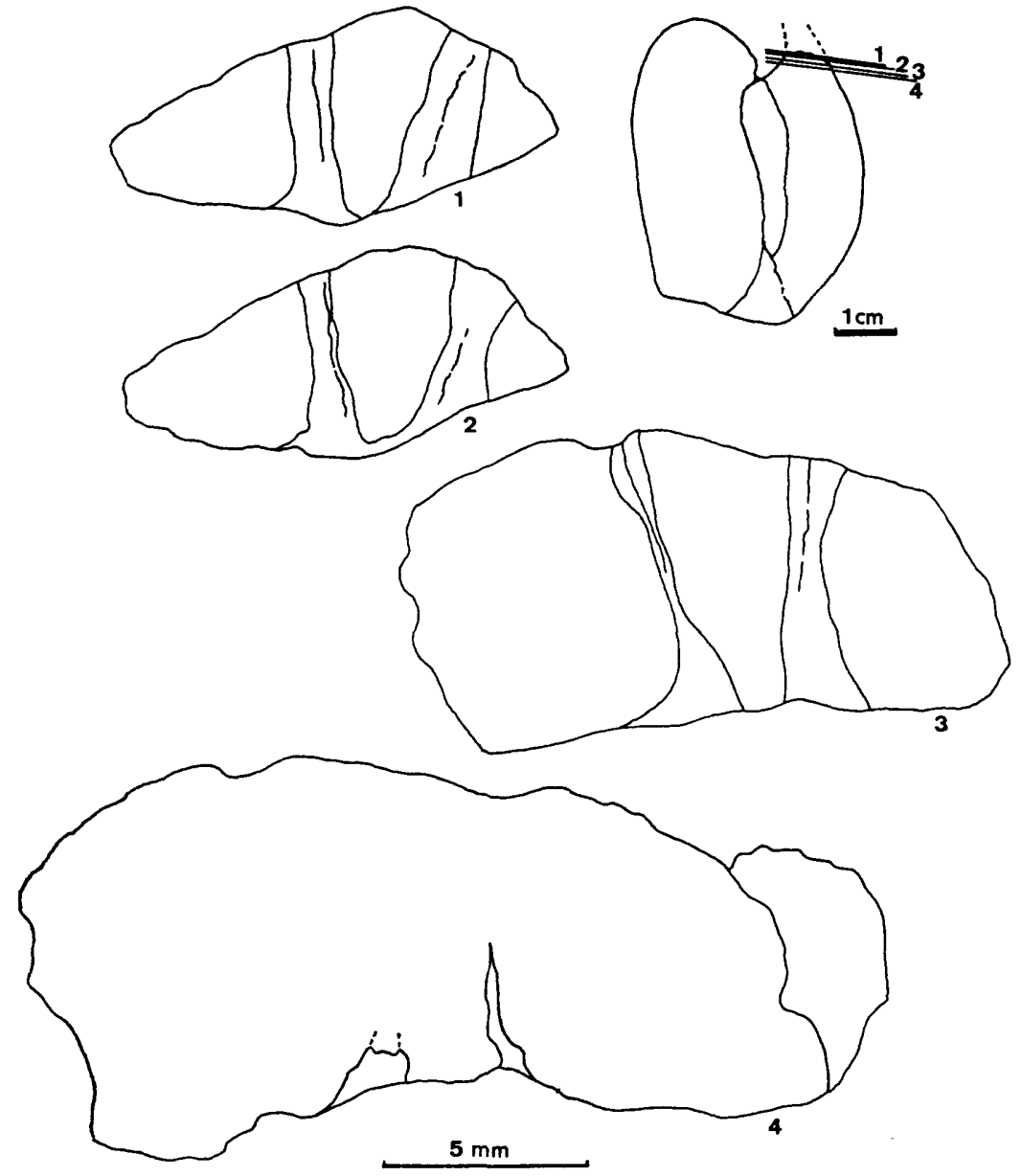

Fig. 14. Purdonella sadai, n. sp. Serial transverse sections of a paratype, GK-D 31629 . 
Remarks.-Purdonella sadai is characterized by its slightly transverse outline with strongly rounded cardinal extremities, very short hinge line with low triangular denticulated area, and commonly bifurcated, low costae with high possibility of having a median broad costa or median broad bifurcated costae along the crest of fold.

Among the allied forms Purdonella magna Hamada (1964) from the Upper Carboniferous of Loei, central-north Thailand is similar to the Japanese species in its external outline and size. The former, however, is distinct from the latter by having simple costae on the whole surface. The hinge line of the former species is relatively much longer than that of the latter. The denticulation of the interarea is coarser in the Thailand species than the Japanese one. Purdonella tschernyschewiformis OzAKI (1931) from the Upper Carboniferous of Liaoning, Northeast China is another alliance to the present species. It resembles $P$. sadai by its transversely rounded outline, broad sulcus and broadly rounded fold, and by its bifurcated costae. Anterior prolongation of sulcus and fold is, however, much stronger in the former and the anterior commissure is much higher than the latter. The interarea of the Japanese species is slightly wider than the Chinese one.

Purdonella nikitini Tschernyschew, the type species of this genus, also resembles the Japanese species by its general outline, although it has the more elevated beak and narrower interarea as comparing with the shell-width than the latter.

The presence of median strong costa or costae along the crest of fold of the present species recalls to the writers mind those in Purdonella multiradiatus described by REED (1944) from the Middle Productus beds of the Salt Range. That species, however, is different from the Japanese one by its more transverse outline and its widest part, locating slightly anterior to the hinge line.

Occurrence.- $\mathrm{K}-1, \mathrm{~K}-2$

\section{Purdonella species undetermined}

Pl. 18, Fig. 8; Pl. 19, Fig. 2

Material.-Two incomplete specimens, GK-D 31630 (pl. 19, fig. 2) and GK-D 31707 (pl. 18, fig. 8), available with following dimension (in $\mathrm{mm}$ ), respectively: length, ca 35 and 42.0 ; width, 38.2 and ca 40 ; length of hinge line, 22.0 and ca 25 ; height of interarea, ca 4 and ca 7 ; thickness, 28.0 and 27.0 ; ratio of hinge line to shell width, 0.58 and ca 0.63 .

Descriptive remarks.- Shell medium for genus, subrounded with nearly equidimensional outline and widest part at about midlength. Pedicle valve strongly convex and somewhat elongated posteriorly with much incurved beak; hinge line much shorter than shell width with remarkably rounded cardinal extremities; interarea small, triangular, slightly concave, and finely denticulated with relatively wide delthyrium in middle; sulcus broad, shallow without distinct boundary between it and lateral slopes; costae low, rounded, and tightly arranged with occasional bifurcation posteriorly, countable about 6 in distance of $5 \mathrm{~mm}$ at slightly posterior to anterior margin, and about 20 in sulcus near 


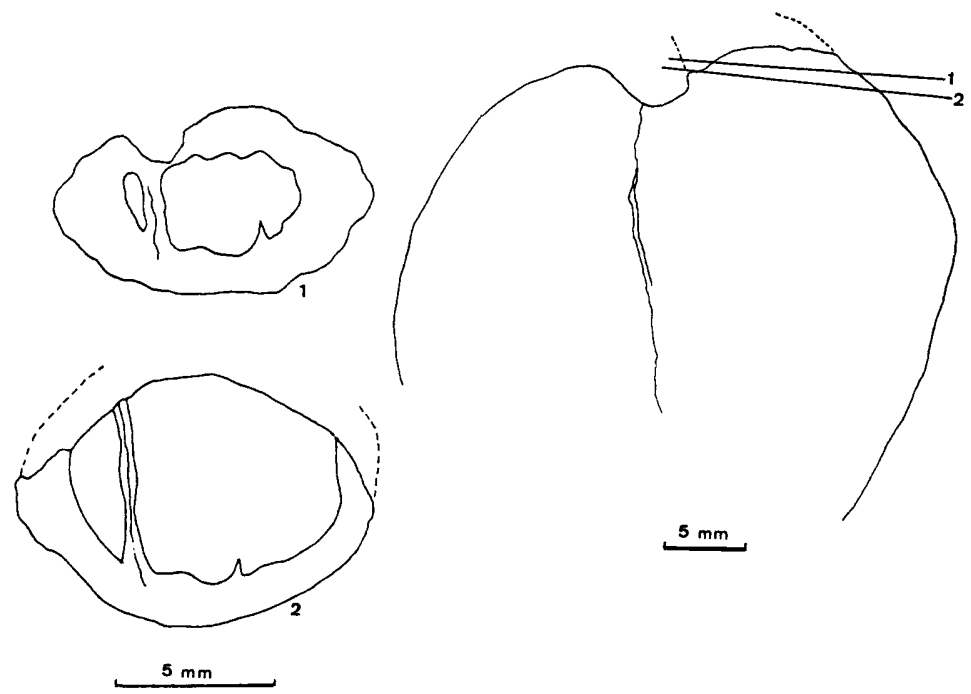

Fig. 15. Purdonella sp. Serial transverse sections of a specimen, GK-D 31707.

anterior margin; anterior commissure gently uniplicate. Brachial valve moderately convex with low incurved beak; fold indistinguishable from lateral slopes but median part longitudinally broadly elevated; ornamentation same with opposite valve.

Pedicle valve interior with thin, short and subparallel dental plates, other structures unknown.

Present species is composed of two incomplete specimens and it is unable to determine the specific position. They have, however, some distinguishable characters from known species of Purdonella, such as subrounded outline with inflated valves and broad sulcus without remarkable anterior prolongation. The rounded outline, triangular area, proportion between hinge line and shell width, and rather inflated valves of the present species recall specimens of Purdonella tschernyschewiformis (OzAKI) from the Upper Carboniferous of Pen-hsi-hsien, Liaoning, Northeast China. The Chinese species may be a close ally to the Japanese species, although it has more remarkable sulcus and fold with anterior prolongation than the present species. Purdonella sadai is distinct from the present species by its more transverse outline. Purdonella nikitini (TsCHERNYSCHEW) from the Lower Permian of the Urals resembles the present species in its outline, but it is distinguished from the latter by its much smaller proportion between hinge line and shell width and having non denticulated interarea.

Occurrence.-K-1, K-2

Order Strophomenida ÖPIK, 1934

Suborder Productidina WAAGEN, 1883

Superfamily Productacea GraY, 1840

Family Retariidae MUIR-Wood and COOPER, 1960 
Subfamily Retariinae MUIR-WOOD and COOPER, 1960

Genus Kutorginella Ivanova, 1951

Type-species.-Kutorginella mosquensis Ivanova, 1951

Kutorginella ? sp.

Pl. 20, Fig. 4; Pl. 21, Fig. 1

Material.-Two fragmentary specimens composed of visceral discs, GK-D 31695 (pl. 21, fig. 1) and GK-D 31604 (pl. 20, fig. 4), briefly described under heading.

Descriptive remarks.-Shell medium to large for genus; widest part may

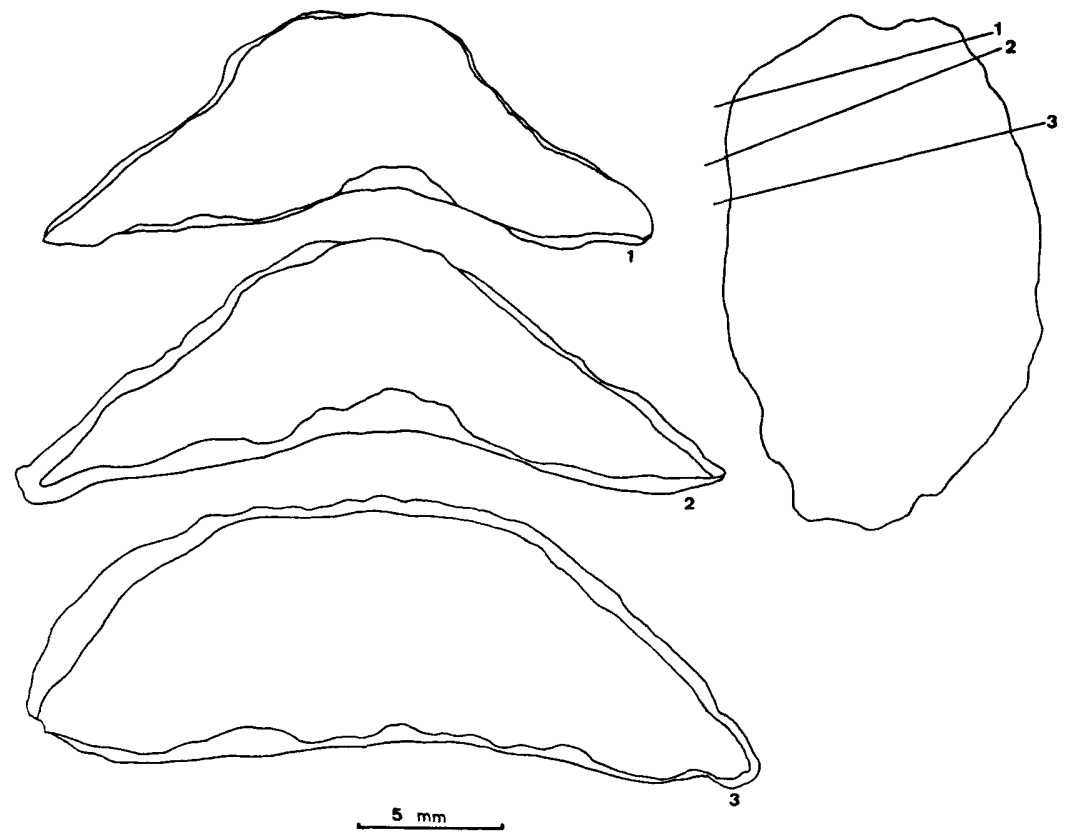

Fig. 16. Kutorginella? sp. Serial transverse sections of an incomplete specimen, GK-D 31695 .

\section{Explanation of Plate 20}

Figs. 1, 3. Neophricadothyris aff. N. catatona CoOPER and Grant ...Page 186 1a-c. Dorsal, ventral, and lateral views of a pedicle valve, GK-D 31710, Loc. $\mathrm{K}-2, \times 1$.

3a-f. Lateral, dorsal, ventral, posterior, and anterior views of a specimen, and the dorsal internal view showing arrangement of spiralia, GK-D 31638 , Loc. $\mathrm{K}-2, \times 1$.

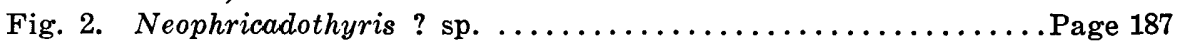
2a-d. Dorsal, posterior, ventral, and lateral views of an incomplete specimen, GK-D 31622, Loc. K-2, ×1.5.

Fig. 4. Kutorginella ? sp. ................................. 192 4a-d. Ventral, lateral, posterior, and anterior views of an incomplete pedicle valve, GK-D 31604, Loc. K-2, $\times 1$. 


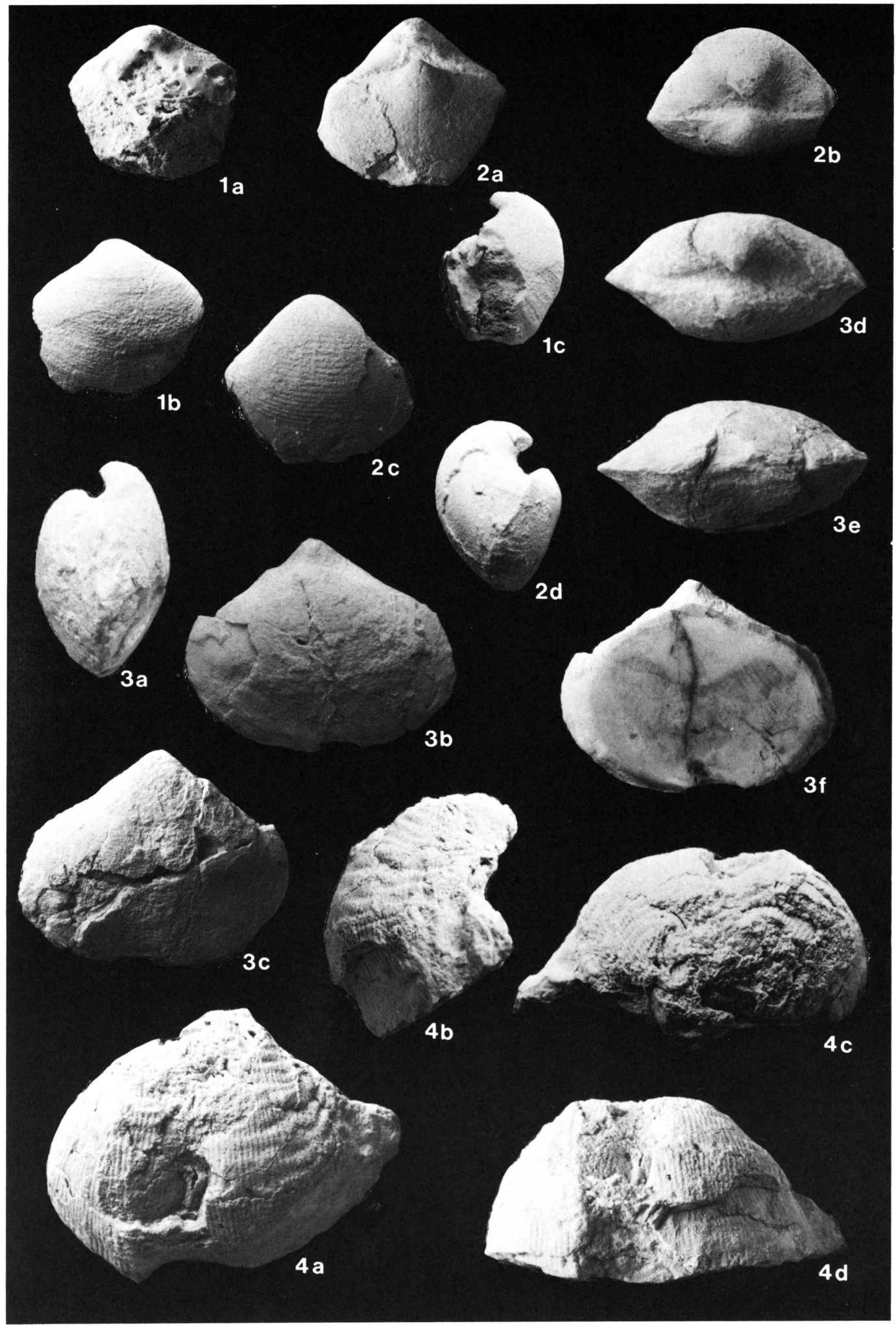

J. YANAGIDA \& I. NishikawA: Permian Brachiopods 


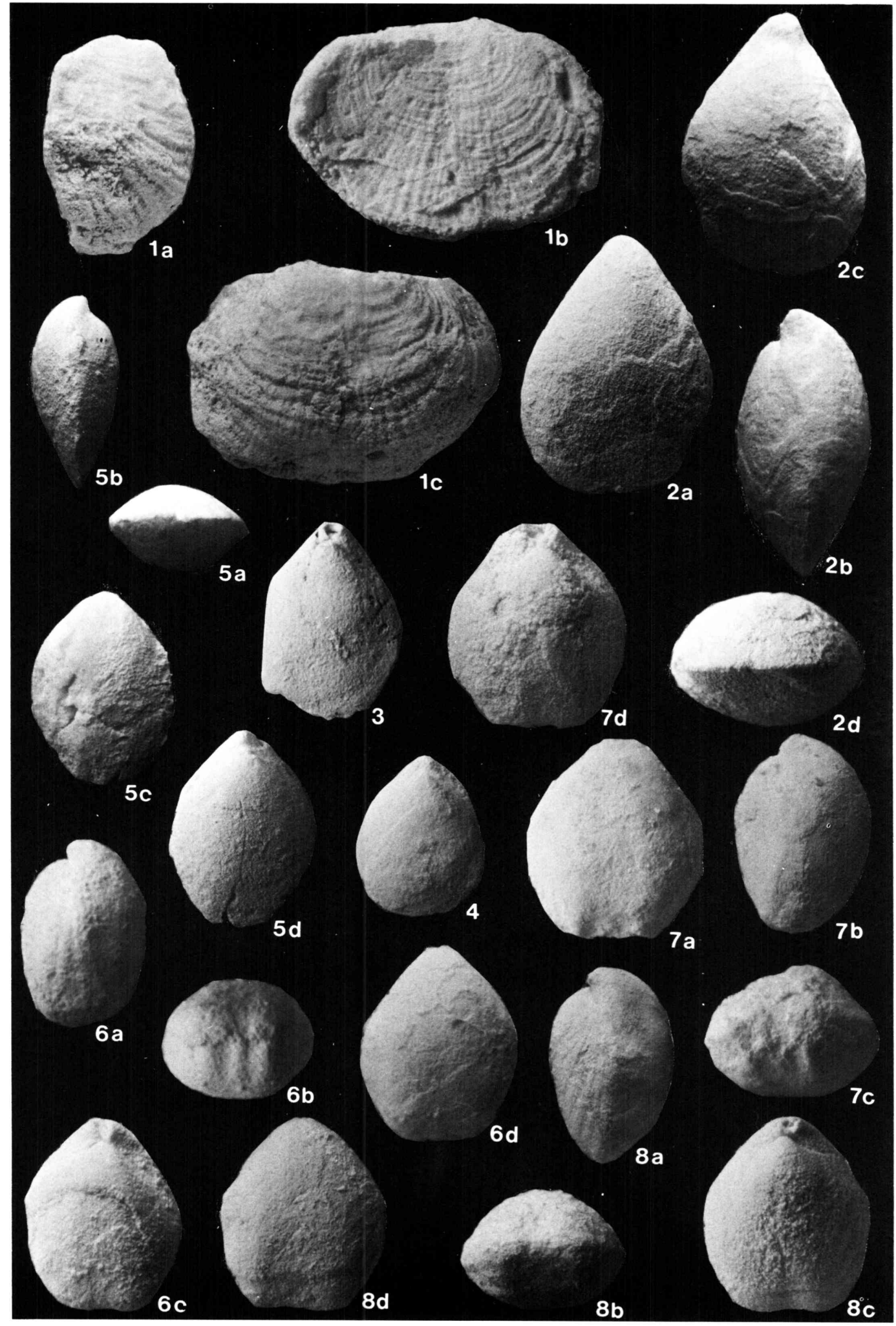

J. Yanagida \& I. Nishikawa: Permian Brachiopods 
anterior to hinge line; profile may geniculate. Pedicle valve moderately convex and shallowly sulcate with slightly convex venter and moderately sloping flanks; surface strongly rugose and finely costate with weak reticulation, rugae stronger in marginal region than other, costae countable 3 to 4 near anterior margin of visceral disc; spine bases of small sizes scattered on venter and on flanks and larger ones occasionally observable near boundary between flank and ear. Brachial valve with slightly concave to nearly flat visceral disc ornamented by weak reticulation, small shallow pits, and only a few minute spine bases. Internally low broad posterior region of dorsal median septum and low marginal ridges only recognized by transverse sections.

The present species is doubtfully referable to Kutorginella owing by its incomplete preservation. Nevertheless ornamental character of visceral region well reveals that of Kutorginella, and as far as it is concerned the Japanese species is similar to Kutorginella aprica described by GRANT (1976) from the Lower Permian of Ko Muk, Southern Thailand, especially by its weak reticulation and mode of spine arrangement.

Occurrence.-K-2

Order Terebratulida WAAGEN, 1883

Suborder Terebratulidina WAAGEN, 1883

Superfamily Dielasmatacea SCHUCHERT, 1913

Family Dielasmatidae SCHUCHERT, 1913

Subfamily Dielasmatinae SCHUCHERT, 1913

Genus Dielasma King, 1859

Type-species.-Terebratulites elongatus Schlotheim, 1816

Dielasma species undetermined

Pl. 21, Figs. 2-5

Material.-Ten, very small juvenile specimens and an adult one available.

\section{Explanation of Plate 21}

Fig. 1. Kutorginella ? sp. ............................... 192

1a-c. Lateral, dorsal, and ventral views of an incomplete specimen, GK-D 31695 , Loc. K-2, $\times 2$.

Figs. 2-5. Dielasma sp. ............................... 193

2a-d. Ventral, lateral, dorsal, and anterior views of a specimen, GK-D 31705 , Loc. $\mathrm{KW}-46$.

3-4. Dorsal views of two specimens, respectively GK-D 31712 and GK-D 31669 , Loc. K-1, $\times 4$.

5a-d. Anterior, lateral, ventral, and dorsal views of a specimen, GK-D 31689, Loc. K-2, $\times 4$.

Figs. 6-8. Chondronia hiroshimensis, n. sp. ....................... 194

6a-d. Lateral, anterior, dorsal, and ventral views of the holotype, GK-D 31665 , Loc. K-2, $\times 4$.

7a-d. Ventral, lateral, anterior, and dorsal views of a paratype, GK-D 31667, Loc. K-2, $\times 4$.

8a-d. Lateral, anterior, dorsal, and ventral views of a specimen, GK-D 31668, Loc. $\mathrm{K}-2, \times 4$. 
Internal structure only partly understood by a transverse section of a specimen, GK-D 31711.

Descriptive remarks.- Shell medium for genus, elongately oval in outline, and uniformly biconvex with slightly larger convexity of pedicle valve; largest width at midlength in juvenile stage but more anterior to midlength in mature stage. Anterior commissure rectimarginate.

Pedicle valve evenly convex in lateral and anterior profile with slightly larger convexity in posterior half. Umbonal region narrow, elevated with slightly incurved beak; foramen small both in juveniles and adult. Surface smooth, flattened on median anterior region, no trace of sulcus observed.

Brachial valve more evenly convex both longitudinally and transversely than opposite valve without fold; umbonal region narrow.

Internal structures only partly known by a transverse section of an incomplete specimen with a part of dental plates and open hinge plates.

Measurements of five specimens in $\mathrm{mm}$.

\begin{tabular}{lrrc} 
& length & width & thickness \\
\hline (GK-D 31705) & 20.5 & 14.5 & 10.0 \\
(GK-D 31712) & 7.9 & 5.6 & 3.2 \\
(GK-D 31713) & 9.2 & 6.6 & 3.3 \\
(GK-D 31689) & 7.6 & 5.5 & 3.5 \\
(GK-D 31690) & 6.4 & 5.0 & 2.8
\end{tabular}

Details of internal structures of the present species are unknown because of recrystalization of the matrix. Externally it has some special characters and it may be distinctive from other known species of Dielasma, if internal characters are well examined by well presedved specimens. External characters are as follows; uniformly convex valves with nearly same convexity of both valves and completely rectimarginate anterior commissure, smooth surface without sulcus and fold, and narrowly erect ventral umbo. In these points of views the Japanese species well resembles a Lower Permian species from the Maping Limestone, Nanthan, Kweichou, South China, described by GrabaU (1936) by the name of Dielasma itaitubense TSCHERNYSCHW. The figured specimens by GrABAU, all have nearly rectimarginate anterior commissure, and then they are distinctive from TSCHERNYSCHEW's specimens characterized by uniplicate anterior commissure.

Grant (1976) described unnamed Permian species of Dielasma from Ko Muk, Thailand, composed of both uniplicate and rectimarginate shells. A figured rectimarginate shell (pl. 68, figs. 6-10) is externally similar to the present specimens.

Occurrence.-KW-46, K-2, K-1

Superfamily Cryptonellacea THomson, 1926

Family Notothyrididae LICHAREW, 1960

Subfamily Notothyridinae LICHAREW, 1960

Genus Chondronia COOPER and Grant, 1976

Type-species.-Chondronia bella COOPER and GRANT, 1976

Chondronia hiroshimensis, new species

P1. 21, Figs. 6-8 
Material.-Holotype, GK-D 31665 (pl. 21, fig. 6) ; Paratypes, GK-D 31667 (pl. 21, fig. 7) and GK-D 31616. Internal structures shown by serial sestions of a specimen, GK-D 31666.

Diagnosis.-Large, oval to elongate oval Chondronia with very slight anterior sulcation and incipient costation at anerior margin.

Description.- Shell medium to large for genus, oval to elongate oval in outline and moderately biconvex in profile with pedicle valve slightly larger in convexity; largest width at midvalve or slightly anterior to it; anterior margin more or less truncated; anterior commissure rectimarginate to weakly paraplicate; surface smooth except for surface near anterior margin with incipiently developed costae and tightly arranged growth lines in adult.

Pedicle valve nearly uniformly convex with largest convexity in umbonal region; anterior view evenly arched with steep lateral margins; anterior folding very delicate, only weak sulcus recognizable by naked eye in juveniles with rectimarginate to minutely folded anterior margin, in adults three costae barely countable in faint sulcus at anterior margin; foramen small to medium for shell.

Brachial valve evenly convex in lateral profile and evenly to medianly strongly elevated with nearly flattened slopes and short, steep lateral margins in anterior profile; anterior margin with slight median depression in juveniles and median depression and faint two costae in adults.

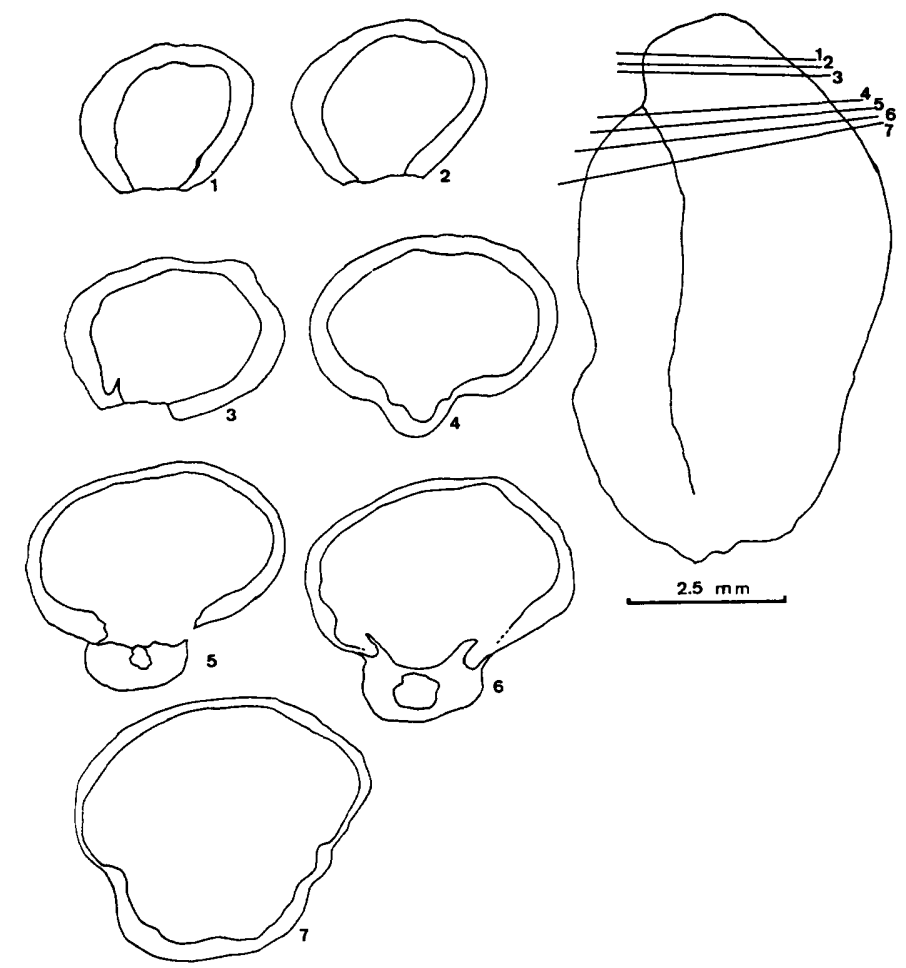

Fig. 17. Chondronia hiroshimensis, n. sp. Serial transverse sections of a specimen, GK-D 31666 . 

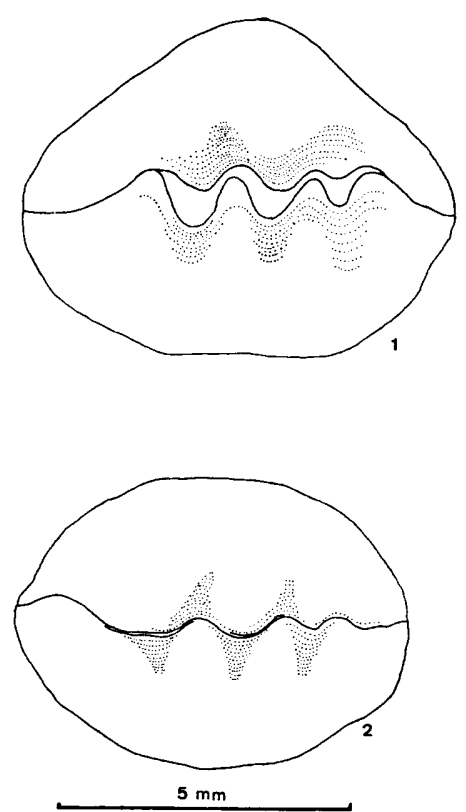

Fig. 18. Chondronia hiroshimensis, n. sp. Examples of variation of mode of anterior commissure; 1 , GK-D 31667 and 2, GK-D 31665.

In pedicle valve interior detailes not recognized. Brachial valve interior with very strong short inner socket ridges, diverging ventrolaterally and centrally continuous to inner hinge plate; others unknown.

Measurements of four specimens in $\mathrm{mm}$ and degree.

\begin{tabular}{lccccc} 
& length & $\begin{array}{c}\text { length of } \\
\text { brachial } \\
\text { valve }\end{array}$ & width & thickness & $\begin{array}{c}\text { apical } \\
\text { angle }\end{array}$ \\
\hline Holotype (GK-D 31665) & 7.7 & 6.8 & 5.9 & 4.7 & ca 56 \\
Paratype (GK-D 31667) & 7.9 & 7.0 & 6.9 & 5.2 & ca 68 \\
Paratype (GK-D 31616) & 7.5 & 6.6 & 6.2 & 4.0 & ca 70 \\
(GK-D 31668) & 7.6 & 6.8 & 6.3 & 4.6 & ca 68
\end{tabular}

Remarks.-Chondronia hiroshimensis is characterized by its larger size for the genus, about twice as large as the average size of Chondronia, anterior sulcation of both valves with very faint, paraplicate anterior commissure in adult shells, and very strongly developed inner socket ridges of brachial valves. Anterior foldings are variable as shown in the Text-fig. 18. Normally the details of folding of the anterior commissure are distinguishable only under microscope.

Six species of Chondronia were described by COOPER and GRANT (1976) from the Lower Permian Wolfcampian to Leonardian of West Texas and they reported that these species are all found from the biohermal limestones, apparently showing inhabitants of this special environment.

Occurrence.-K-2 


\section{References Cited}

BroIll, F. (1916): Die permischen Brachiopoden von Timor. In J. WANNER and F. Weber (eds.), Erggebnisse der Expeditionen G.A.F. MolengraAFF, VII : 1-104, pls. 1-13.

Cooper, G. A. and Grant, R. E. (1976): Permian brachiopods of West Texas, V. Smith. Contr. Paleobiol., (24), 2609-2923, pls. 663-780.

Feng, R. (1978) : Brachiopoda. In paleontological atlas of Southwest China. Kueichow volume (2). Carboniferous to Quaternary volume. Kueichow Committee on Strat. Paleont. (ed.). 231-305, pls. 85-108.

Grabau, A. W. (1931): The Permian of Mongolia. Natural History of Central Asia 4. 665 p., 53 pls. Amer. Mus. Nat. Hist. New York.

(1934): Early Permian fossils of China, I: Early Permian Brachiopods, Pelecypods and Gastropods of Kueichow. Geol. Surv. China, Palaeont. Sinica [B], 8, (3), 1-168, pls. 1-11.

(1936) : Early Permian fossils of China, II : Fauna of the Maping Limestone of Kwangsi and Kueichow. Ibid., [B], 8, (4), 1-441, pls. 1-31.

Grant, R. E. (1976) : Permian brachiopods from southern Thailand. Jour. Paleont., 50, (3), Supplement, pt II of II, 1-269 (pls. 1-71).

Hamada, T. (1964) : Two Carboniferous brachiopods from Loei, Thailand. Japan. Jour. Geol. Geogr., 35, (1), 5-15, pl. 1.

Lr, L. and GU, F. (1976): Carboniferous and Permian brachiopoda. In Paleontological atlas of North China. Inner Mongolia volume (1). Paleozoic volume. Northeast Inst. Geol. Science (ed.). 228-306, pls. 131-184. Geol. Publishing House, Beijing.

LI, L., GU, F., and SU, Y. (1980): Carboniferous and Permian brachiopoda. In paleontological atlas of Northeast China (1). Paleozoic volume. Shenyang Inst. Geol. Min. Resources (ed.). 327-428, pls. 145-180. Geol. Publishing House Beijing.

Leven, E. Ya. (1981) : Permian-Tethys Stage scale and correlation of sections of the Mediterranean-Alpine folded belt. I.G.C.P. No. 5 Newsletter., 3, 100-112.

OzakI, K. (1931): Upper Carboniferous brachiopods from North China. Bull. Shanghai Sci. Inst., 1, (6), 1-205, pls. 1-15.

Pavlova, E. E. (1965): Revizhiya Roda Neophricodothyris (Otryad Spiriferida). Paleont. Zhurnal, 1965 (2), 133-137. Revision of the genus Neophricodothyris (Order Spiroferida). Translation in Intern. Geol. Rev., 8, (1), 84-88.

(1969): Razvitie brachiopod semeistva Reticulariidae. Trud. Paleont. Inst., 120, 1-124, pls. 1-13.

REed, F. R. C. (1944) : Brachiopoda and mollusca from the Productus Limestones of the Salt Range. Geol. Surv. India Mem., Palaeont. Indica, n.s., 23, (2), 1-678, pls. 1-65.

SADA, K., OKImura, Y. and Imamura, S. (1979) : On the Kawai Limestone in Konu County, Hiroshima Prefecture, Japan. Mem. Fac. Int. Arts and Sci., Hiroshima Univ., [4], 4, 23-27.

Tschernyschew, T. N. (1902): Die obercarbonischen Brachiopoden des Ural und des Timan. Mem. Com. Geol. St. Petersburg., 16, (2), 1-749, pls. 1-63.

WAagen, W. H. (1882-1885) : Salt Range Fossils, pt. 4: 2 Brachiopoda. Geol. Surv. India Mem., Palaeont. Indica, [13], 1, 329-770, pls. 25-86.

Waterhouse, J. B. and Piyasin, S. (1970): Mid-Permian Brachiopods from Khao Phrik, Thailand. Paleontographica, 135, A, 83-197, pls. 14-32.

YANAGIDA, J. (1970): Permian brachiopods from Khao Phrik, near Rat Buri, Thailand. Geol. Palaeont. SE Asia, 8, 69-96, pls. 14-16.

YaNAGidA, J. and Hirata, M. (1969): Lower Permian brachiopods from Nakakubo, west-central Shikoku, Japan. Trans. Proc. Paleont. Soc. Japan, N. S., (73), $89-111$, pls. $10,11$. 